\section{Ankara Üniversitesi Eğitim Bilimleri Fakültesi Özel Eğitim Dergisi}

2022, 23(3), 507-535

\section{ARAȘTIRMA}

Gönderim Tarihi: 03.07.20

Kabul Tarihi: 21.07.21

Erken Görünüm: 24.09.21

\title{
Gelişimsel Yetersizliği Olan Öğrencilere Doğrudan Öğretim Yöntemiyle İşlevsel Matematik Becerilerinin Öğretiminin Etkililiği*
}

\author{
Özer Akgün ${ }^{(D)} 1$
}

Oğuz Gürsel $\mathbb{D}^{2}$

Öz

Giriş: Özel gereksinimli öğrencilerin işlevsel matematik becerileri ile gerek ev ortamında gerekse sosyal yaşamda her an karşılaşması mümkündür. Dolayısıyla kesir okuma, madeni para sayma ve saat söyleme gibi işlevsel matematik becerilerinin öğretiminin, çocuğun günlük yaşama uyumuna katkı sağlayacağı düşünülmektedir. $\mathrm{Bu}$ araştırmanın amacı, gelişimsel yetersizliği olan öğrencilere doğrudan öğretim yöntemiyle işlevsel matematik becerilerinin (buçuk/yarım saatleri söyleme, aynı madeni paraların toplam miktarını söyleme ve kesirleri söyleme/okuma) öğretiminin etkililiğini araştırmaktır.

Yöntem: Araştırmanın yöntemi, tek denekli araştırma yöntemlerinden yoklama evreli davranışlar arası çoklu yoklama modelidir. Araştırma, 9-10 yaşlarında gelişimsel yetersizliği olan 3 öğrenciyle gerçekleştirilmiştir. Araştırmanın bağımlı değişkeni işlevsel matematik becerilerini söyleme becerisi, bağımsız değişkeni ise doğrudan öğretim yöntemidir. Bu araştırmada etkililik verileri, güvenirlik verileri ve sosyal geçerlik verileri olmak üzere üç çeşit veri toplanmıştır.

Bulgular: Araştırma bulguları, gelişimsel yetersizliği olan öğrencilere işlevsel matematik becerilerinden buçuk saatleri söyleme, aynı madeni paraların toplam miktarını söyleme ve kesirleri söyleme becerisinin öğretiminde doğrudan öğretim yönteminin etkili olduğunu göstermektedir. Öğrencilerin öğretim bittikten 5,7 ve 12 gün sonra işlevsel matematik becerilerini korudukları ve farklı araç-gereçlere genelleyebildikleri gözlenmiştir.

Tartışma: Araştırmaya katılan tüm öğrencilerin öğretimi gerçekleştirilen işlevsel matematik becerilerine ilişkin öğretim öncesi ve öğretim sonrası performanslarının anlamlı bir şekilde arttığı görülmektedir. Gelişimsel yetersizliği olan çocuğa sahip ailelere, sınıf öğretmenlerine ve özel eğitim öğretmenlerine işlevsel matematik becerilerinin öğretiminde doğrudan öğretim yöntemini kullanmaları önerilebilir.

Anahtar sözcükler: Gelişimsel yetersizlik, doğrudan öğretim yöntemi, işlevsel matematik becerileri, buçuk saat, madeni para sayma, kesir becerisi.

Atıf için: Akgün, Ö., \& Gürsel, O. (2022). Gelişimsel yetersizliği olan öğrencilere doğrudan öğretim yöntemiyle işlevsel matematik becerilerinin öğretiminin etkililiği. Ankara Üniversitesi Ĕgitim Bilimleri Fakültesi Özel Ĕgitim Dergisi, 23(3), 507-535. https://doi.org/10.21565/ozelegitimdergisi.763670

\footnotetext{
*Bu çalışma Lefke Avrupa Üniversitesi Lisansüstü Eğitim Öğretim ve Araştırma Enstitüsünde Dr. Öğr. Üyesi Oğuz Gürsel danışmanlığında Özer Akgün tarafından 2018-2019 eğitim-öğretim yılında yapılan yüksek lisans tez çalışmasından hazırlanmıştır. Aynı zamanda çalışma, 29. Ulusal Özel Eğitim Kongresinde sözlü bildiri olarak sunulmuştur.

${ }^{1}$ Sorumlu Yazar: Uzm., Milli Eğitim Bakanlığı, E-posta: ozer.akgn@ hotmail.com, https://orcid.org/0000-0001-5130-7924

${ }^{2}$ Dr. Öğr. Üyesi, Lefke Avrupa Üniversitesi, E-posta: gurselogz@gmail.com, https://orcid.org/0000-0002-4320-210X
} 


\section{Giriş}

Özel gereksinimli bireylerin kendilerine özgü özelliklerinden dolayı öğrenme ihtiyaçları da farklılık göstermektedir. Özellikleri ve ihtiyaçları doğrultusunda "bireyi merkez alan" eğitim modeliyle ve eğitim programıyla öğrenimlerine devam etme hakları vardır. Eğitim modelinin veya programın amacına uygun olarak öğrenme ve öğretme sürecinde bireyin özelliklerine uygun yöntem ve teknikler seçilmelidir (Özel Eğitim Hizmetleri Yönetmeliği, 2018). Uygulamalı davranış analizi ve yanlışsız öğretim yöntemleri gibi doğrudan öğretim de özel gereksinimli bireylerin eğitiminde kullanılan etkili yöntemler olarak alanyazında yer almaktadır (Burns \& Ysseldyke, 2009; Hill \& MacMillan, 2004; Tekin, 1999).

Doğrudan öğretim, pek çok eğitimci tarafından "Eski moda" öğretim biçimi olarak anılsa da araştırma temelli bir öğretim yaklaşımıdır (Vukmir, 2002). İlk kez 1960'ların sonlarında özel eğitime ihtiyacı olan öğrencilerle birlikte kullanılmaya başlayan doğrudan öğretim, günümüzde de özel eğitim öğrencilerinin eğitimi için kullanılmaktadır (Hill \& MacMillan, 2004). Bu yaklaşımın temel ilkesi; öğretimde planlı, tam ve hatasız öğrenme deneyimleri sağlayarak öğretimin çocukların öğrenebileceği bir şekilde tasarlanması gerektiğidir. Doğrudan geri bildirim ve olumlu pekiştirme, bu yöntemin önemli unsurlarıdır. Bu yöntemde kullanılan doğrudan geri bildirim ve olumlu pekiştirme, geleneksel eğitim sisteminden farklı olarak çocuğa açıç̧a sunulmakta ve çocuk doğrudan pekiştirilmektedir. Etkili olduğu kanttlanan bu yöntem somut ve uygulamalı etkinliklerle öğretimi öğrenci merkezli öğrenmeye dönüştürür. Üç aşamalı öğretim süreci "Yaparım, Yaparız ve Yaparsın" şeklinde ifade edilir (Hill \& MacMillan, 2004). Doğrudan öğretim yönteminin basamakları; a) programa dayalı değerlendirme, b) öğretimi planlama, c) hazırlık aşaması, d) model olma, e) rehberli uygulamalar, f) geri dönüt ve düzeltme, g) bağımsız uygulamalar, h) kalıcılıktır (Gürsel, 2017).

Gelişimsel yetersizliği olan bireylerin, akademik ve işlevsel matematik becerilerini içeren bir eğitime ihtiyacı vardır. İşlevsel matematik becerileri; zamanı söyleme, para kullanma ve ölçme gibi gerçek hayattaki durumları öğretmeye odaklanır (Burton vd., 2013). Özel gereksinimli öğrencilerin eğitim programlarında işlevsel akademik becerilerin (para saymak, zaman yönetimi, tabela okumak vb.) yer alması gerekmektedir. Özel gereksinimli öğrencilerin eğitim programlarında yer alan bu beceriler gerçek hayatla ilişkilendirilerek öğretilmelidir. Normal gelişim gösteren öğrenciler gibi özel gereksinimli öğrencilerin de okulda öğrendikleri bilgileri günlük hayatta kullanması temel amaçlardan biridir (Gürsel, 2017).

Gelişimsel yetersizliği olan çocukların, görsel-algısal belleklerinin zayıf olması ve mantıksal düşünme becerisindeki yetersizlikler nedeniyle kesirleri anlamada zorluk çektiği düşünülmektedir (Grobecker, 2000). Kesir kavramının öğretiminde görsel materyaller kullanmak, bu kavramın kazanılmasında oldukça önemlidir (Suh \& Moyer, 2008). Kesir kavramının kazandırılmasında; "En alttaki sayı her gruptaki parça sayısını, en üstteki sayı kullandığınız parça sayısını gösterir.” şeklinde özel yöntemler önerilmektedir (Grobecker, 2000). Gelişimsel yetersizliği olan öğrenciler, farklı miktardaki paraları hesaplama becerisi kazanırsa, parasal işlemlerde günlük hayatta daha bağımsız olurlar. Gelişimsel yetersizliği olan öğrenciler 5 kuruşları beşer, 10 kuruşları onar, 25 kuruşları yirmi beşer ve 50 kuruşları ellişer sayarak madeni paraları hesaplama becerisini kazanırlar (Kalaycı, 2014). Ritmik sayma davranışııı öğretiminde, öğretmenler daha çok küçük sayıları $(2,3,4,5,6$, 7, 8, 9 ve 10'arlı ritmik sayma) kullanarak öğretim yapmaktadırlar. Büyük sayılarla ilgili öğretime yeteri kadar yer vermedikleri gözlenmektedir. Öğretmenler, 100 'e kadar 25'er 25'er sayma davranışını öğrencilerin para becerilerini öğrenmesi için gerekli görmektedirler. Bu nedenle, para becerilerinin öğretiminde daha büyük sayıların ( 25 ve $50 \mathrm{krş})$ öğretimine yer vermek gerekmektedir. Ayrıca her bir para becerisinin değeri farkl1llk göstermektedir. Bu bağlamda; paraların toplam miktarını söyleme becerisinin öğretiminin, ritmik sayma davranışından farklılaşan yönü ise öğrencilere değer kavramının kazandırılmasıdır (Stein vd., 2005). Gelişimsel yetersizliği olan bireylere saat söyleme becerisinin öğretimi kolaydan zora doğru bir sıra izlemelidir. Tam saatler, yarım saatler (buçuk), çeyrek geçe, çeyrek kala ve beş dakika ve dakikalar şeklinde bir sırayla öğretim gerçekleştirilmelidir (Gürsel, 2017).

Gelişimsel yetersizliği olan bireyler, günlük yaşamda kullanabilecekleri becerilere ihtiyaç duyarlar. Okulda öğrendikleri bilgileri günlük yaşamda da kullanabilmeleri amaçlanmaktadır (Gürsel, 2017). Bu amaca uygun olarak araştırmadaki becerilerin seçiminde; becerilerin hem işlevsel olması hem de zamanı söyleme, para kullanma ve ölçme gibi öğrencilerin ders programlarında yer alan beceriler olmasına dikkat edilmiştir. Gelişimsel yetersizliği olan öğrencilerle para becerileri, saati okuma ve kesirleri söyleme konularında hem yurt dışı hem de Türkiye'de yapılan çalışmalar incelenmiştir.

Gelişimsel yetersizliği olan bireylere, kesirler konusunun öğretimiyle ilgili yurt dışında yapılan çalışmalar incelendiğinde, kesirler konusuna yönelik bazı araştırmalara (Bottge \& Hasselbring, 1993; Bottge vd., 2002; Butler 

BECERILERININ ÖĞRETIMININ ETKILILİĞİ

vd., 2003; Flores \& Kaylor, 2007; Grobecker, 2000; Joseph \& Hunter, 2001; Lewis, 2016; Misquitta, 2011; Suh \& Moyer, 2008; Test \& Ellis, 2005) ulaşılmıştır. Ancak Türkiye'de kesirler konusunun öğretimine yönelik herhangi bir çalışmaya rastlanmamıştır. Bu nedenle bu araştırma Türkiye'de gelişimsel yetersizliği olan öğrencilere yönelik kesirler konusunda yapılacak ilk çalışma olması açısından önemlidir.

Alanyazında gelişimsel yetersizliği olan öğrencilerle para becerileri konusunda Türkiye'de (Buğan, 1999; Erbaş, 2008; Kalayc1, 2014; Kurtoğlu vd., 2017; Öncül \& Özkan-Yücesoy, 2010; Şahin, 2017; Şenbel-Erten, 1996; Tümeğ \& Sazak-Pınar, 2016; Yıkmış vd., 2006; Yüksel, 2012) ve yurt dışında (Borakove \& Cuvo, 1977; Denny \& Test, 1995; Frank \& Mcfarland, 1980; Llorente \& Gaffan, 1989; Lowe \& Cuvo, 1976; Schloss vd., 1997; Test vd., 1993; Trace vd., 1977; Waters \& Boon, 2011) bazı araştırmalara rastlanmıştır. Yurt dışında gelişimsel yetersizliği olan bireylerle yapılan çalı̧̧maların çoğu madeni paraları sayma becerisine yöneliktir. Türkiye'de gelişimsel yetersizliği olan bireylere yönelik para becerileriyle ilgili yapılan çalışmalarda araştırmacıların; paraları eşleme, paraları tanıma ve farklı bileşenlerini söyleme, para kullanımını öğretme, para kullanarak ürün satın alma, bankamatikten para çekme, para tanıma uygulaması geliştirme konularında çalışmalar yürüttükleri görülmüştür. Çalışmaların çoğunun paraları tanıma becerisi konusunda yoğunlaştığı görülmektedir. Madeni paraları sayma becerisinin öğretimiyle ilgili bir çalışmaya rastlanmamıştır. Sadece Buğan'ın (1999) çalışması (paraların farklı bileşenlerini söyleme) madeni paraları sayma becerisiyle benzerlik göstermektedir. Ancak bu çalışmada öğrencilerin beceriyi gerçekleştirme durumları tespit edilmiş olup, madeni paraları sayma becerisine yönelik herhangi bir öğretim gerçekleştirilmemiştir. Bu yönüyle de yapılacak bu araştırma Türkiye'de gelişimsel yetersizliği olan öğrencilerle madeni paraları sayma becerisinin öğretimine yönelik yapılacak ilk çalışma olması açısından önemlidir.

Alanyazında gelişimsel yetersizliği olan öğrencilerle zaman kavramı ve saati söyleme konusunda yurt dışında (Andersson, 2008; Burny vd., 2011; Desoete, 2009; Eden vd., 2003; Horn vd., 2006; Kibby vd., 2002; Thompson vd., 2012) ve Türkiye'de (Birkan, 2012; Dağseven, 2001; Karabulut \& Yıkmış, 2010; Tufan vd., 2020) yapılan sınırlı sayıda çalışmaya rastlanmıştır. Türkiye'de, gelişimsel yetersizliği olan öğrencilere saatleri söyleme becerisinin öğretimine yönelik dört çalışma (Birkan, 2012; Dağseven, 2001; Karabulut \& Y1kmış, 2010; Tufan vd., 2020) yer almaktadır. Birkan (2012) ve Dağseven (2001) çalışmasında tam, buçuk, çeyrek geçe ve çeyrek kala saatleri, Karabulut ve Yıkmış (2010) çalışmasında tam, buçuk ve çeyrek geçe saatleri, Tufan ve diğerleri (2020) ise çalışmasında tam saatleri söyleme becerisinin öğretimini gerçekleştirmiştir. Türkiye'de gelişimsel yetersizliği olan öğrencilerle buçuk saatleri söyleme becerisinin öğretimine yönelik yapılacak bu çalışma alanyazına katkı sağlayacak olması açısından önemlidir. Ayrıca bu çalışmanın gelişimsel yetersizliği olan öğrencilerin işlevsel matematik becerilerini öğrenmesine katkı sağlayacağı düşünülmektedir. Yapılan araştırmalar sonucunda, gelişimsel yetersizliği olan bireylerin eğitiminde doğrudan öğretim yönteminin etkili olduğu görülmüştür (Birkan, 2012; Dağseven, 2001; Flores \& Kaylor, 2007; Lowe \& Cuvo, 1976; Tufan vd., 2020). Ancak doğrudan öğretim yöntemi kullanılarak gelişimsel yetersizliği olan bireylere işlevsel matematik becerilerinden saat söyleme becerisinin öğretimine ilişkin sadece üç çalı̧̧maya (Birkan, 2012; Dağseven, 2001; Tufan vd., 2020), kesirleri söyleme ve madeni paraları sayma becerisinin öğretimine ilişkin ise herhangi bir çalışmaya rastlanmamıştır.

Gelişimsel yetersizliği olan öğrencilerin kesirleri söyleme, madeni paraları sayma ve saati söyleme gibi işlevsel matematik becerileriyle gerek ev ortamında gerekse sosyal yaşamda her an karşıllaşması mümkündür. Gelişimsel yetersizliği olan öğrenciler, farklı miktardaki paraları hesaplama becerisi kazanırsa, parasal işlemlerde günlük hayatta daha bağımsız olurlar. Gelişimsel yetersizliği olan bireyler analog saatleri söylemekte dijital saatlere göre daha çok zorlanırlar (Desoete, 2009). Ancak günümüzde yaygın olarak evde, okulda veya iş yerlerinde analog saatler bulunmaktadır. Bu nedenle öğrencilere analog saatleri okuma becerisini öğretmek daha işlevsel bir beceri olacaktır. Markette alışveriş yaparken "yarım kilo şeker, çeyrek ekmek" gibi günlük hayatta kesir kavramını içeren ifadeler kullanırız. Dolayısıyla kesir okuma, madeni para sayma ve saat söyleme gibi işlevsel matematik becerilerinin çocuğun günlük yaşama uyumuna katkı sağlayacağı düşünülmektedir. $\mathrm{Bu}$ gereksinimden dolayı araştırmaya ihtiyaç duyulmuştur.

Araştırmanın genel amacı, gelişimsel yetersizliği olan öğrencilere doğrudan öğretim yöntemiyle işlevsel matematik becerilerinin öğretiminin etkililiğini belirlemektir. Bu amaçla çalışmada; "Doğrudan öğretim yöntemi, gelişimsel yetersizliği olan öğrencilerin işlevsel matematik becerilerini a) edinmelerinde, b) sürdürmelerinde, c) farklı materyallere genellemelerinde etkili midir?" sorularına yanıt aranmaktadır. Ayrıca çalışmada sosyal geçerliğin belirlenmesi amaçlanmaktadır. 


\section{Yöntem}

\section{Araştırma Modeli}

Bu araştırmada gelişimsel yetersizliği olan öğrencilerin doğrudan öğretim yöntemiyle işlevsel matematik becerilerinin öğretiminin etkililiğini sınamak için tek denekli araştırma modellerinden yoklama evreli davranışlar arası çoklu yoklama modeli kullanılmıştır. Tek denekli araştırma deseni, gelişimsel yetersizlikten etkilenmiş öğrenciler için özel eğitimde kullanılan önemli desenlerdendir. Tek denekli araştırma deseni, bağımsız değişkenlerin etkisiyle bağımlı değişkenlerde meydana gelen değişimin kanıtlarını deneysel olarak sunmaktadır (Horner vd., 2005). Yoklama evreli çoklu yoklama modelinde, tüm durumlarda eşzamanlı bir şekilde kararlı veri elde edilene kadar başlama düzeyi verisi toplanır. Kararlı veri alındıktan sonra birinci durumda uygulamaya geçilir ve uygulama boyunca sürekli veri toplanır. Birinci durumda kararlı veri alındıktan sonra ikinci durumda uygulamaya geçilir. Tüm durumlarda ölçüt karşılanıncaya kadar bu süreç devam etmektedir (Kırcaali-İftar \& Tekin, 1997). Araştırmanın bağımlı değişkeni, işlevsel matematik becerilerinden buçuk saatleri (1:30, 2:30, 3:30, 4:30, 5:30, 6:30, 7:30, 8:30, 9:30, 10:30, 11:30, 12:30) \%80 düzeyinde, aynı madeni paraların (5 kuruş, 10 kuruş ve 25 kuruş) toplam miktarını \%100 düzeyinde ve kesirleri (1/2,1/3, 2/3, 2/4 ve 3/4) \%100 düzeyinde söyleme becerisidir. Araştırmanın bağımsız değişkeni, işlevsel matematik becerilerinin öğretiminde kullanılan doğrudan ögretim yöntemidir.

\section{Katılımcılar}

Çalışmaya katılacak öğrencilerde; (a) 1'den 25'e kadar sayıları tanıma, (b) tam saatleri söyleme, (c) akrep için kısa kol, yelkovan için uzun kol diyebilme, (d) beşer, onar ve yirmi beşer ritmik sayma, (e) beş kuruşu, on kuruşu ve yirmi beş kuruşu tanıma, (f) parça-bütün ilişsisini kavrama, (g) bütün, yarım ve çeyrek kavramlarını kavrama ön koşul becerilerine sahip olmaları aranmıştır. Kaynaştırma ortamlarında yer alan sekiz özel gereksinimli öğrenciyle işlevsel matematik becerilerinin öğretimi için önkoşul becerileri yoklama oturumları gerçekleştirilmiştir. Oturumlarda verilerin kaydedilmesi için her beceriye yönelik ayrı ayrı Önkoşul Becerileri Yoklama Oturumları Veri Kayıt Formu kullanılmıştır. Öğrencilerin doğru cevapları için “+” yanlış veya cevap vermemeleri durumunda “-”" işareti konulmuştur. Önkoşul becerilerde 3/3 ölçütü kullanılmıştır. Önkoşul becerileri yoklama oturumları sonunda sekiz öğrenciden beşinin işlevsel matematik becerilerinin öğretimi için uygunluğuna karar verilmiştir. Araştırma üç öğrenciyle yürütülecek şekilde planlanmış ve bir öğrenci de yedek olarak seçilmiştir. Araştırma başlamadan önce uygulama sürecinde ortaya çıkabilecek olası aksaklıkları belirlemek için de bir öğrenciyle pilot uygulama gerçekleştirilmiştir. Pilot uygulama sürecinde çalışmaya yönelik; a) araç-gereci hazırlama, b) dikkati sağlama, c) beceri yönergesini sunma, d) kontrol edici ipucunu sunma, e) davranış sonrası uyaran sunma, f) denemeler arası süre, g) katılımı pekiştirme başlıkları altında uygulama güvenirliğine bakılmıştır. Pilot uygulama sonucunda süreçte herhangi bir değişiklik yapılmamasına karar verilmiştir.

Bu araştırmaya Kuzey Kıbrıs Türk Cumhuriyeti’ndeki Girne Karaoğlanoğlu İlkokulunda genel eğitim 4. sınıfa devam eden, aynı zamanda Psikolojik Danışma, Rehberlik ve Araştırma Şubesinden (PDRAŞ) aldığı rapor ile destek eğitim odasında eğitim gören gelişimsel yetersizliği olan iki erkek bir kız olmak üzere toplam üç özel gereksinimli öğrenci katılmıştır. İki öğrenci 9, bir öğrenci 10 yaşındadır. Araştırma öncesinde, belirlenen öğrencilerin aileleriyle görüşülmüş ve çalışmaya katılabilmeleri konusunda ailelerden izin alınmıştır. Ayrıca okul idaresinden araştırma için imzalı onay alınmıştır. Öğrencilere kod isimler verilmiştir. Öğrencilerin özellikleri Tablo 1'de gösterilmiştir.

\section{Tablo 1}

Araştırmaya Katılan Öğrenciler ve Özellikleri

\begin{tabular}{lcccc}
\hline İsim & Cinsiyet & Yaş & Sinıf & Okula devam \\
\hline Mert & Erkek & 10 & 4 & 2 yıl \\
Emir & Erkek & 10 & 4 & 5 yıl \\
Ayşe & Kiz & 9 & 4 & 4 y1l \\
\hline
\end{tabular}

Mert, okulunda iki yıldır eğitim almakta ve aynı zamanda destek eğitim odasında özel eğitim desteği almaktadır. Öz bakım, günlük yaşam becerilerini ve psikomotor becerileri yerine getirebilmektedir. Kendisine verilen yönergeleri yerine getirmekte ve herhangi bir iletişim sorunu yaşamamaktadır. Karşılıklı konuşmalarda anlamlı cümleler kurmakta ve olayları oluş sırasına göre anlatabilmektedir. Bir etkinliğe 25 dakika boyunca dikkati dağılmadan katılabilmektedir. Matematik becerilerinde ise 1'den 100'e kadar sayabilmektedir. Üç basamaklı doğal sayıları ayırt edebilmektedir. Üç basamaklı doğal sayıları rakamlar ile yazabilmektedir. Beşer, onar ve yirmi beşer ritmik sayabilmektedir. Tek basamaklı sayılarda toplama işlemi yapabilmektedir. İki basamaklı sayılarda eldesiz 

BECERILERININ ÖĞRETIMININ ETKILILIĞĞI

toplama işlemini bağımsız bir şekilde gerçekleştirememektedir. Çıkarma işleminde yeterli bir performans gösterememektedir. Saatin uzun (yelkovan) ve kısa (akrep) kolunu tanımaktadır. Tam saatleri söyleyebilmektedir. Parça-bütün ilişkisini ve bütün, yarım ve çeyrek kavramlarını ayırt etmektedir. Beşgen, altıgen, silindir, küp gibi bir üst seviye geometrik şekilleri ayırt etmektedir. Madeni ve kağıt paraları tanımaktadır.

Emir, okulunda beş yıldır eğitim almakta ve aynı zamanda destek eğitim odasında özel eğitim desteği almaktadır. Birinci sınıfta sınıf tekrarı yapmıştır. Öz bakım, psikomotor ve günlük yaşam becerilerini kazanmıştır. Kendisine verilen yönergeleri yerine getirmektedir. Alıcı dil becerilerinde herhangi bir sorun yaşamamaktadır. İfade edici dil becerilerinde artikülasyon ve sınırlı düzeyde kekemelik sorunu yaşamaktadır. Bir etkinliğe 20 dakika boyunca dikkati dağılmadan katılabilmektedir. Matematik becerilerinde ise 1'den 100'e kadar sayabilmekte ve yazabilmektedir. Üç basamaklı doğal sayıları ayırt edebilmektedir. Üç basamaklı doğal sayıları rakam ve yazı ile yazmaktadır. İkişer, üçer, beşer, onar ve yirmi beşer ritmik sayabilmektedir. İki basamaklı sayılarla eldesiz toplama işlemi yapabilmektedir. İki basamaklı sayılarda eldeli toplama işlemini bağımsız bir şekilde gerçekleştirememektedir. İki basamaklı sayılarda onluk bozma gerektirmeyen çıkarma işlemini yapabilmektedir. Saatin uzun (yelkovan) ve kısa (akrep) kolunu tanımaktadır. Tam saatleri söyleyebilmektedir. Parça-bütün ilişkisini ve bütün, yarım ve çeyrek kavramlarını ayırt etmektedir. Kare, üçgen, dikdörtgen ve daire gibi basit geometrik şekilleri ayırt etmektedir. Madeni ve kağıt paraları tanımaktadır.

Ayşe, okulunda dört yıldır eğitim almakta ve aynı zamanda destek eğitim odasında özel eğitim desteği almaktadır. Öz bakım, psikomotor ve günlük yaşam becerilerini kazanmıştır. Kendisine verilen yönergeleri yerine getirmektedir. Karşılıklı konuşmalarda anlamlı cümleler kurar. Olayları oluş sırasına göre anlatabilmektedir. Bir etkinliğe 25 dakika boyunca dikkati dağılmadan katılabilmektedir. Matematik becerilerinde ise 100'e kadar bağımsız sayabilmekte ve yazabilmektedir. Dört basamaklı doğal sayıları ayırt etmektedir. Dört basamaklı doğal sayıları rakam ve yazı ile yazmaktadır. İkişer, beşer, onar ve yirmi beşer ritmik saymaktadır. İki basamaklı sayılarla eldesiz ve eldeli toplama işlemi yapabilmektedir. İki basamaklı sayılarda onluk bozma gerektirmeyen çıkarma işlemini yapabilmektedir. Saatin uzun (yelkovan) ve kısa (akrep) kolunu tanımaktadır. Tam saatleri söyleyebilmektedir. Parça-bütün ilişkisini ve bütün, yarım ve çeyrek kavramlarını ayırt etmektedir. Kare, üçgen, dikdörtgen ve daire gibi basit geometrik şekilleri ayırt etmektedir. Madeni ve kağıt paraları tanımaktadır.

\section{Ortam ve Materyaller}

Araştırmanın başlama düzeyi, öğretim, yoklama, genelleme ve izleme oturumları Girne Karaoğlanoğlu İlkokulu'nun destek eğitim odasında bire bir oturum şeklinde gerçekleştirilmiştir. Destek eğitim odası yaklaşık $5 \times 10$ metrekare boyutlarındadır. Duvarları beyaz renge boyalı, duvarın üst kısmında duvarı boydan boya kaplayan büyük bir pencere, yazı tahtası, iki adet duvar panosu ve Atatürk portresi bulunmaktadır. Odada araç-gereçlerin koyulduğu ikisi kapalı biri açık üç bölmeli bir dolap, bir öğretmen masası, bir ofis koltuğu, üç fasulye tipi öğrenci masası, üç öğrenci sandalyesi, bir ayaklı tahta, bir laptop ve bir yazıcı yer almaktadır.

Öğretim süreci için kullanılan materyaller; (a) buçuk saatlere ilişkin ön camı ve saniye kolu çıkarılmış, analog gerçek duvar saati, (b) madeni paralara ilişkin beşer adet madeni 5 kuruş, 10 kuruş ve 25 kuruş ve (c) kesirlere ilişkin farklı parçalara bölünmüş, bazı parçaları yeşil renge boyanmış daire şeklinde ve $22 \times 22 \mathrm{~cm}$ boyutunda altı adet PVC kaplı kesir öğretim materyali hazırlanmıştır. Genelleme oturumu için kullanılan materyaller; (a) buçuk saatlere ilişkin ön camı ve saniye kolu çıkarılmış, analog gerçek masa saati, (b) madeni paralara ilişkin beş adet madeni 5 kuruş, beş adet madeni 10 kuruş ve beş adet madeni 25 kuruş resminin olduğu çalışma kağıdı ve (c) kesirlere ilişkin farklı parçalara bölünmüş ve bazı parçaları yeşil renge boyanmış altı adet dikdörtgen şeklinin olduğu çalışma kağıdı hazırlanmıştır. Ayrıca oturumlardaki verileri kaydetmek için becerilere uygun "Veri Kayıt Formu" hazırlanmıştır. Araştırmanın yoklama ve öğretim oturumları video kamerayla kayıt altına alınmıştır.

\section{Uygulama Süreci ve Pilot Uygulama}

Uygulamaya başlamadan önce öğretim esnasında ortaya çıkabilecek olası aksaklıkları belirlemek ve araştırmacının uygulama kontrolünü sağlamak için uygulamaya katılacak öğrenciler dışında farklı bir öğrenciyle üç pilot uygulama oturumu gerçekleştirilmiştir. Pilot uygulama oturumlarında, kullanılacak araç-gereçlerin kullanışlılığı ve kayıt cihazının çalışıp çalışmadığı kontrol edilmiştir. Süreçte herhangi bir değişiklik yapılmamasına karar verildikten sonra pilot uygulama oturumları sonlandırılmış ve uygulama sürecine geçilmiştir.

Araştırmada uygulama süreci doğrudan öğretim yöntemiyle gerçekleştirilmiştir. Uygulama sürecinde; başlama düzeyi, öğretim, günlük yoklama, toplu yoklama, genelleme ve izleme oturumları gerçekleştirilmiştir. 

BECERILERININ ÖĞRETIMININ ETKILILİĞII

Öğrencilere uygulama sürecinde doğrudan öğretim yöntemiyle işlevsel matematik becerilerinden buçuk saatleri söyleme, aynı madeni paraların toplam miktarını söyleme ve kesirleri söyleme becerilerinin kazandırılması amaçlanmıştır. Uygulama üç öğrenciyle de bire bir öğretim düzenlemesiyle gerçekleştirilmiştir. Uygulama sürecinde beceriler arasındaki etkileşim etkisini kontrol edebilmek için öğrencilere beceriler farklı sıralarla sunulmuştur. Mert ile sırasıyla; aynı madeni paraların toplam miktarını söyleme, buçuk saatleri söyleme, kesirleri söyleme öğretim oturumları düzenlenmiştir. Emir ile sırasıyla; buçuk saatleri söyleme, kesirleri söyleme, aynı madeni paraların toplam miktarını söyleme öğretim oturumları düzenlenmiş̦tir. Ayșe ile sırasıyla; kesirleri söyleme, aynı madeni paraların toplam miktarını söyleme, buçuk saatleri söyleme öğretim oturumları düzenlenmiştir. $\mathrm{Bu}$ araştırmada ölçüt, buçuk saatleri söyleme becerisi için $\% 80$, aynı madeni paraların toplam miktarını söyleme becerisi için $\% 100$ ve kesirleri söyleme becerisi için $\% 100$ olarak belirlenmiştir. Tam saatleri söyleme becerisinde saatin kısa kolu herhangi bir saati net bir şekilde gösterirken, buçuk saatleri söyleme becerisinde saatin kısa kolu ardışı iki saatin arasını göstermektedir. Saatin sağ yarısında kısa kolun üstünde kalan saat söylenirken, saatin sol yarısında kısa kolun altındaki saatin söylenmesi de öğrencilerin buçuk saatleri söyleme becerisini öğrenmelerini zorlaştıracağ düşünülmüsştür. Bu nedenle buçuk saatleri söyleme becerisi için ölçüt \% 80 olarak belirlenmiştir.

Öğretimi gerçekleştirilecek becerilerle ilgili öğretim öncesi öğrencilerin mevcut performansları ile öğretim sonu performanslarını karşılaştırarak, kullanılan yöntemin etkililiğini ortaya koymak için öğretime başlamadan önce öğrencilerle eş zamanlı olarak art arda tüm becerilere yönelik en az üç kararlı veri elde edilene kadar başlama düzeyi yoklama oturumları düzenlenmiştir. Başlama düzeyi oturumlarından sonra öğrencilerle öğretim oturumları gerçekleştirilmiştir. Öğretim oturumlarında; öğrenci, birinci becerinin öğretiminde ölçütü karşılar düzeyde performans gösterip ve en az üç kararlı veri elde edilince tüm becerilere yönelik öğrenciyle toplu yoklama oturumları düzenlenmiştir. Birinci becerinin öğretiminden sonra düzenlenen toplu yoklama oturumlarında en az üç kararlı veri elde edildikten sonra ikinci becerinin öğretimine geçilmiştir. Öğrenci, ikinci becerinin öğretiminde ölçütü karşılar düzeyde performans gösterip ve en az üç kararlı veri elde edilince tüm becerilere yönelik toplu yoklama oturumları düzenlenmiştir. İkinci becerinin öğretiminden sonra düzenlenen toplu yoklama oturumlarında en az üç kararlı veri elde edildikten sonra üçüncü becerinin öğretimine geçilmiştir. Öğrenci, üçüncü becerinin öğretiminde de ölçütü karşılar düzeyde performans gösterip ve en az üç kararlı veri elde edilince tüm becerilere yönelik son kez toplu yoklama oturumları düzenlenmiştir. Bu işlem üç öğrenci için de uygulanmıştır. Becerilerin öğretimini sonlandırmak için öğrencilerin belirlenen ölçütü üç oturum üst üste göstermeleri amaçlanmıştır. Üç oturum üst üste her beceri için belirtilen ölçüte ulaşıldıktan sonra beş, yedi ve on iki gün sonra izleme verisi toplanmıştır. Ayrıca tüm becerilerde ölçüte ulaşıldıktan hemen sonra her beceri için ayrı ayrı araç-gereçler arası genelleme oturumları düzenlenmiştir.

\section{Başlama Düzeyi Oturumları}

Başlama düzeyi yoklama oturumlarının amacı; öğretimi gerçekleştirilecek becerilerle ilgili öğretim öncesi öğrencilerin mevcut performansları ile öğretim sonu performanslarını karşılaştırarak, kullanılan yöntemin etkililiğini ortaya koymaktır. Bu yüzden öğretim öncesinde öğrencilerle eş zamanlı olarak art arda tüm becerilere yönelik en az üç kararlı veri elde edilene kadar başlama düzeyi yoklama oturumları düzenlenmiştir. Öğretimsel amaç olarak alınan her beceri için başlama düzeyi yoklama oturumunda üç deneme yapılmıştır. Başlama düzeyi yoklama oturumlarında süreç şu şekilde düzenlenmiştir: Öğretmen ve öğrenci sınıftaki çalışma masasına karşılıklı oturmuştur. Öğrenci hazır olduğunda öğretmen buçuk saatleri söyleme becerisi için öğretim materyalinden ilk buçuk saati göstererek "Saat kaç?" diye öğrenciye sormuştur. Aynı madeni paraların toplam miktarını söyleme becerisi için masanın üstündeki beş adet 5 kuruşu göstererek "Toplam kaç lira var?" diye öğrenciye sormuştur. Kesirleri söyleme becerisi için kesir öğretim materyalinden ilk şekli göstererek "Şeklin kesrini söyle." diye öğrenciye sormuştur. Öğrenciden alınan veriler başlama düzeyi yoklama oturumu veri kayıt formuna işlenmiştir. Oturum sonunda "Aferin! Çalışmaya katıldın. Sana teşekkür ederim." şeklinde öğrenci davranışı öğretmen tarafindan sözel olarak pekiştirilmiştir.

\section{Öğretim Oturumlart}

Öğretim oturumlarında becerilerin öğretimi aşağıdaki hedefe ve sıraya göre gerçekleştirilmiştir: Para becerisine yönelik öğrencilerin; beş adet 5 kuruşu beşer ritmik sayarak 25 kuruş diyebilme, beş adet 10 kuruşu onar ritmik sayarak 50 kuruş diyebilme ve beş adet 25 kuruşu yirmi beşer ritmik sayarak 125 kuruş diyebilmesi; saat becerisine yönelik öğrencilerin; analog duvar saatinde 1:30 gösterildiğinde "bir buçuk", 2:30 gösterildiğinde "iki buçuk", 3:30 gösterildiğinde "üç buçuk", 4:30 gösterildiğinde "dört buçuk", 5:30 gösterildiğinde "beş buçuk", 6:30 gösterildiğinde "altı buçuk", 7:30 gösterildiğinde "yedi buçuk", 8:30 gösterildiğinde "sekiz buçuk", 9:30 
gösterildiğinde "dokuz buçuk", 10:30 gösterildiğinde "on buçuk", 11:30 gösterildiğinde "on bir buçuk" ve 12:30 gösterildiğinde "on iki buçuk" diyebilmesi; kesir becerisine yönelik öğrencilerin; 1/2 kesri gösterildiğinde "bir bölü iki”, 1/3 kesri gösterildiğinde "bir bölü üç”, $2 / 3$ kesri gösterildiğinde "iki bölü üç”, $2 / 4$ kesri gösterildiğinde "iki bölü dört" ve $3 / 4$ kesri gösterildiğinde "üç bölü dört" diyebilmesi hedeflenmiştir. Para becerisine yönelik “Toplam kaç lira var var?", saat becerisine yönelik "Saat kaç” ve kesir becerisine yönelik "Şeklin kesrini yaz ve söyle." yönergeleri sunulmuştur.

a) Model Olma. Buçuk saatleri söyleme becerisi için öğretmen öğrenciye "Şimdi seninle buçuk saatleri söyleyeceğiz. Buçuk saatleri söylemeye hazır mısın?" diye sorarak öğrenciyi çalı̧̧maya hazır hale getirmek istemiştir. Öğrenci çalışmaya hazır olduğunu sözel olarak ifade ettikten veya jest ve mimik gibi sözel olmayan ifadelerle (başını sallama vb.) gösterdikten sonra öğretmen öğrenciyi motive etmek için "Aferin, çok güzel. Çalışmaya başlayabiliriz." diyerek öğrencinin bu davranışını pekiştirmiştir. Buçuk saatleri söyleme becerisi için öğretmen duvar saatini eline almış ve bir buçuk (1:30) için "Saatin kısa kolunu 1 ile 2 arasında getirdim. Ardından saatin uzun kolunu 6'nın üzerine getirdim ve saat bir buçuk" demiştir. Diğer buçuk saatlere yönelik süreç aynı şekilde yürütülmüsşür. Oturumlarda dikkat sağlayıcı ipucu olarak "Buçuk saatleri söyleyeceğiz." uyaranı kullanılmıştır.

Aynı madeni paraların toplam miktarını söyleme becerisine yönelik öğretmen öğrenciye "Seninle paraların toplam miktarını söyleyeceğiz. Masanın üstünde 5 kuruşlar var. Bu nedenle paraları beşer beşer sayarak toplam kaç lira olduğunu bulacağım" der. Ardından öğretmen 5 kuruşları tek tek ayırarak saymaya başlar. Tüm paralar1 5 kuruş, 10 kuruş, 15 kuruş, 20 kuruş, 25 kuruş şeklinde toplayarak sayar ve " 25 kuruş var." demiştir. Diğer madeni paralara yönelik süreç aynı şekilde yürütülmüştür. Oturumlarda dikkat sağlayıcı ipucu olarak "Paraların toplam miktarını söyleyeceğiz." uyaranı kullanılmıştır.

Kesir okuma becerisine yönelik öğretmen öğrenciye "Seninle şeklin kesrini söyleyeceğiz." der. Ardından öğretmen, kesir okuma becerisine yönelik öğretim materyali olan daire şeklini eline alır ve öğrenciye "Daire şeklinin tüm parçalarını sayıp kesir çizgisinin altına kaç tane olduğunu yazdım. Ardından daire şeklinin sadece boyalı parçalarını sayıp kesir çizgisinin üstüne kaç tane olduğunu yazdım ve bu şeklin kesri bir bölü iki” demiştir. Diğer kesirlere yönelik süreç aynı şekilde yürütülmüştür. Oturumlarda dikkat sağlayıcı ipucu olarak "Şeklin kesrini söyleyeceğiz." uyaranı kullanılmıştır.

b) Rehberli Uygulamalar. Öğretmen, iki kez model olduktan sonra öğrenme sorumluluğunu aşamalı olarak öğrenciye bırakmak için rehberli uygulamalar aşamasına geçilmiştir. Buçuk saatleri okuma becerisine yönelik öğretmen öğrenciye "Şimdi sen de saatin kısa kolunu 1 ile 2 arasına getir." demiştir. Öğrenci işlemi yaptıktan sonra "SSimdi de saatin uzun kolunu 6'nın üzerine getir." demiş̧tir. Sonra öğretmen öğrenciye "Saat kaç?" diye sormuştur. Öğrenci doğru cevap verdiğinde "Aferin" diye pekiştirilmiş, yanlış cevap verdiğinde ise öğretmen düzeltici dönüt olarak "Saat bir buçuk" ipucunu vermiştir. Aynı madeni paraların toplam miktarını söyleme becerisine yönelik öğretmen öğrenciye "Masanın üstünde 5 kuruşlar var. Bu yüzden paraları beşer beşer say ve toplam kaç lira var, söyle." demiştir. Öğrenci doğru cevap verdiğinde "Aferin" diye pekiştirilmiş, yanlış cevap verdiğinde ise öğretmen düzeltici dönüt olarak " 25 kuruş var" ipucunu vermiştir. Kesir okuma becerisine yönelik öğretmen öğrenciye "Şimdi sen de daire şeklinin tüm parçalarını sayıp kesir çizgisinin altına kaç tane olduğunu yaz." demiştir. Öğrenci işlemi yaptıktan sonra "Şimdi de daire şeklinin sadece boyalı parçalarını sayıp kesir çizgisinin üstüne kaç tane olduğunu yaz ve bu şeklin kesrini söyle.” demiştir. Öğrenci doğru cevap verdiğginde "Aferin" diye pekiştirilmiş, yanlış cevap verdiğginde ise öğretmen düzeltici dönüt olarak "bir bölü iki" ipucunu vermiştir.

Rehberli uygulamalar aşamasında öğrenciye verilen ipuçları aşamalı olarak geri çekilmiştir. Saat okuma becerisine yönelik ilerleyen aşamalarda öğretmen sadece "Saat kaç." diye sormuş, aynı madeni paraların toplam miktarını söyleme becerisine yönelik öğretmen sadece "Toplam kaç lira var?" diye sormuş ve kesir okuma becerisine yönelik öğretmen sadece "Şeklin kesrini söyle." diye sormuştur. Rehberli uygulamalar aşamasında iki denemenin ardından öğrenci kendisinden istenen beceriyi yerine getiremiyorsa model olma aşamasına geri dönülmüştür. Öğrenci iki denemenin ardından kendisinden istenen beceriyi yerine getirebiliyorsa bağımsız uygulamalar aşamasına geçilmiş̧ir.

c) Bağımsız Uygulamalar. Öğretmen bu aşamada saat becerisine, para becerisine ve kesir becerisine yönelik öğrenciye hiçbir yardımda bulunmamıştır. Öğretmen sadece; saat becerisine yönelik "Saat kaç?", para becerisine yönelik "Toplam kaç lira var?" ve kesir becerisine yönelik "Şeklin kesrini söyle." diye sormuştur. Öğrenci bu aşamada iki denemenin ardından ilgili beceriyi bağımsız olarak yapamadığında öğretmen tekrar rehberli uygulamalar aşamasına dönmüştür. 

BECERILERININ ÖĞRETIMININ ETKILILIĞĞI

Öğretim oturumunda, ilk beceride ölçüt karşılandıktan sonra tüm becerilere yönelik toplu yoklama oturumları düzenlenmiştir. Ardından ikinci becerinin öğretimine geçilmiştir. İkinci beceride de ölçüt karşılandıktan sonra yine tüm becerilere yönelik toplu yoklama oturumları düzenlenmiştir. Ardından üçüncü becerinin öğretimi gerçekleştirilmiştir. Üçüncü beceride de ölçüt karşılandıktan sonra öğretim oturumları sonlandırılmış ve yine aynı şekilde tüm becerilere yönelik toplu yoklama oturumları düzenlenmiştir. Öğretim oturumlarında, öğretim setindeki becerilere yönelik iki kez deneme gerçekleştirilmiştir. Hafta içi her gün tüm öğrencilerle uygulama yapılacak şekilde bire bir öğretim oturumları düzenlenmiştir. Her oturum 20 dakika olarak planlanmıştır.

\section{Günlük Yoklama Oturumları}

Günlük yoklama oturumları, öğretimi yapılan beceriye yönelik her öğretim oturumunun ardından öğrencinin öğretim sonu performansını belirlemek amacıyla düzenlenmiştir. Günlük yoklama oturumlarının toplu yoklama oturumlarından tek fark1 tüm becerilerde değil, sadece öğretimi yapılan beceriye yönelik veri toplanmasıdır. Günlük yoklama oturumlarında elde edilen veriler veri kayıt formuna işlenmiş̧tir. Öğretimi gerçekleştirilen beceriye yönelik günlük yoklama oturumlarında öğrenci art arda en az üç kararlı veri gösterdiğinde diğer becerinin öğretimine geçilmiştir.

\section{Toplu Yoklama Oturumlart}

Öğrencilerin ölçütü karşllayacak düzeyde performans göstermesi ve öğrencilerden kararlı veri elde edildikten sonra her öğrenciye ve her beceriye yönelik ayrı ayrı düzenlenen oturumlardır. Toplu yoklama oturumları ölçüt karşılandıktan sonra üç beceriye yönelik ayrı ayrı ve öğrencilerle bire bir oturum şeklinde düzenlenmiştir. Öğrenciler, birinci becerinin öğretiminde ölçütü karşılar düzeyde performans gösterip ve en az üç kararlı veri elde edilince tüm becerilere yönelik öğrencilerle toplu yoklama oturumları düzenlenmiştir. Birinci becerinin öğretiminden sonra düzenlenen toplu yoklama oturumlarında en az üç kararlı veri elde edildikten sonra ikinci becerinin öğretimine geçilmiştir. Öğrenciler, ikinci becerinin öğretiminde ölçütü karşılar düzeyde performans gösterip ve en az üç kararlı veri elde edilince tüm becerilere yönelik toplu yoklama oturumları düzenlenmiştir. İkinci becerinin öğretiminden sonra düzenlenen toplu yoklama oturumlarında en az üç kararlı veri elde edildikten sonra üçüncü becerinin öğretimine geçilmiştir. Öğrenciler, üçüncü becerinin öğretiminde ölçütü karşılar düzeyde performans gösterip ve en az üç kararlı veri elde edilince tüm becerilere yönelik son kez toplu yoklama oturumları düzenlenmiştir.

\section{Genelleme Oturumlart}

Genelleme oturumları ön-test ve son-test şeklinde düzenlenmiştir. Araştırmada araç-gereçler arası genelleme gerçekleştirilmiştir. Ön-test genelleme oturumları başlama düzeyi yoklama oturumundan hemen sonra, son-test genelleme oturumları ise tüm becerilerde ölçüt karşılandıktan hemen sonra düzenlenmiştir. Genelleme oturumları farklı araç-gereçlerle bire bir öğretim düzenlemesi şeklinde gerçekleştirilmiş̧ir. Genelleme oturumlarında; buçuk saatleri söyleme becerisi için gerçek duvar saati yerine gerçek masa saati, aynı madeni paraların toplam miktarını söyleme becerisi için gerçek madeni paralar yerine beşer adet beş kuruş, on kuruş ve yirmi beş kuruşların yer aldığı çalışma kağıdı ve kesirleri söyleme becerisi için daire şekli yerine dikdörtgen şeklindeki kesir materyali kullanılmıştır.

\section{Izleme Oturumları}

İzleme oturumları, öğretim oturumları bittikten sonra öğrencilerin öğrendikleri becerileri beş, yedi ve on iki gün sonra ne düzeyde koruduklarını belirleyebilmek için düzenlenmiştir. İzleme oturumlarında, öğrencilere yönelik herhangi bir öğretim gerçekleştirilmemiştir. Sadece öğrencilerin doğru tepkileri pekiştirilmiş, yanlış tepkileri ve tepkide bulunmama durumları görmezden gelinmiş̧ir.

\section{Verilerin Toplanması}

$\mathrm{Bu}$ araştırmada etkililik verileri, güvenirlik verileri ve sosyal geçerlik verileri olmak üzere üç çeşit veri toplanmıştır. Etkililik verilerin toplanmasında; öğrencilerden başlama düzeyi oturumlarında, günlük ve toplu yoklama oturumlarında, öğretim, izleme ve genelleme oturumlarında veri toplanmıştır. Veriler toplanırken iki çeşit öğrenci tepkisi toplanmıştır. Öğrencinin doğru tepkileri için veri kayıt formunda yer alan 'Doğru Tepki' sütununa “+” işareti, yanlış tepkileri için 'Yanlış Tepki' sütununa "--" işareti ve tepkide bulunmama durumunda ise 'Tepkide Bulunmama' sütununa "-" işareti konulmuştur. Öğrencinin tepkide bulunmadığı durumlarda da öğrenci davranışı yanlış tepki olarak kabul edilmiştir. Etkililik verileri "Başlama Düzeyi Yoklama Oturumları Veri Kayıt Formu, Toplu Yoklama Oturumları Veri Kayıt Formu, Günlük Yoklama Oturumları Veri Kayıt Formu, Genelleme 

BECERILERININ ÖĞRETIMININ ETKILILIĞĞI

Oturumları Veri Kayıt Formu ve İzleme Oturumları Veri Kayıt Formu” kullanılarak toplanmıştır. Güvenirlik verilerinin toplanmasında; gözlemciler arası güvenirlik ve uygulama güvenirliği şeklinde iki çeşit güvenirlik verisi toplanmıştır.

\section{Gözlemciler Arası Güvenirlik}

Araştırmanın en az \%30’unda gözlemciler arası güvenirlik ve uygulama güvenirliği verileri toplanmıştır. Yoklama, öğretim, genelleme ve izleme oturumlarının en az \%30'unda gözlemciler arası güvenirlik verisi toplanmıştır. Gözlemciler arası güvenirlik verileri Psikolojik Danışma ve Rehberlik mezunu olup bu alanda yüksek lisans yapmış ve halen doktora yapmakta olan bir uzman tarafından toplanmıştır. Gözlemciye araştırma başlamadan öncesinde konu hakkında sözel olarak bilgi verilmiş ve doğrudan öğretim yöntemi anlatılmıştır. Ayrıca gözlemciye araştırma hakkında bilgilerin yer aldığı "Gözlemci Bilgilendirme Formu” verilmiştir. Gözlemci araştırmaya bizzat katılmış ve her bir oturumu izlemiştir. Güvenirlik hesaplamalarında gözlemciler arası güvenirlik katsayısının \%80 olması yeterli görülmüştür. Araştırmadan elde ettiği veriler "Gözlemciler Arası Güvenirlik Veri Kayıt Formu" ile kaydedilmiştir.

\section{Uygulama Güvenirliği}

Uygulama güvenirliği verilerinin toplanmasında; (a) araç-gereci hazırlama, (b) dikkati sağlama, (c) beceri yönergesini sunma, (d) kontrol edici ipucunu sunma, (e) davranış sonrası uyaran sunma, (f) denemeler arası süre ve (g) katılımı pekiştirme basamakları dikkate alınarak veri toplanmıştır. Uygulama güvenirliği için toplanan veriler "Uygulama Güvenirliği Veri Kayıt Formu” kullanılarak kaydedilmiştir.

Sosyal geçerlik verileri, araştırmaya katılan öğrencilerin sınıf öğretmenlerinin araştırma hakkında görüşleri alınarak toplanmıştır. Sosyal geçerlik verileri, öğretmenler ile bire bir görüşme yapılarak toplanmıştır. Sosyal Geçerlik Veri Toplama Formu aracılığıyla araştırmaya katılan öğrencilerin sınıf öğretmenlerinin araştırma hakkında görüşleri alınmıştır. Sosyal Geçerlik Veri Toplama Formunda dokuz kapalı uçlu, bir açık uçlu soru yer almıştır. Kapalı uçlu sorular "Evet, Hayır, Bilmiyorum" seçeneklerinden oluşan Likert Tipi üçlü dereceleme biçiminde sunulmuştur. Açık uçlu soru ise kısa cevap verilecek şekilde hazırlanmıştır.

\section{Verilerin Analizi}

Doğrudan öğretim yönteminin etkililiğine yönelik elde edilen veriler grafiksel analiz yoluyla analiz edilmiştir. Hazırlanan grafiğin yatay eksenini oturum sayısı, düşey eksenini ise hedef davranışa yönelik doğru tepki yüzdesi oluşturmaktadır. Genelleme oturumlarına yönelik veriler ön test-son test modeliyle analiz edilerek sütun grafikle gösterilmiştir. Araştırmanın izleme oturumlarına yönelik elde edilen veriler grafiksel analiz yoluyla analiz edilmiştir. Araştırmanın gözlemciler arası güvenirlik verileri, "Görüş Birliğgi / Görüş Birliği + Görüş Ayrılığı × 100” formülüyle analiz edilmiştir. Uygulama güvenirliği verileri ise Uygulama güvenirliği verisi toplamak için “Gözlenen Uygulamacı Davranışı / Planlanan Uygulamacı Davranışı × 100” formülüyle analiz edilmiştir. Uygulama güvenirliği analizinde saat becerisi için on iki, para becerisi için üç ve kesir becerisi için ise beş basamak yer almıştır. Sosyal geçerlik verilerinin analizinde; kapalı uçlu sorular betimsel olarak analiz edilmiştir. Açık uçlu soruda ise nitel olarak içerik analizi yapılmıştır.

\section{Bulgular}

\section{Etkililiğe İlişkin Bulgular}

Gelişimsel yetersizliği olan öğrencilere doğrudan öğretim yöntemiyle işlevsel matematik becerilerinin öğretimi ile elde edilen veriler Mert, Emir ve Ayşe için sırasıyla Grafik 1, Grafik 2 ve Grafik 3'te gösterilmektedir. Grafikte yer alan veriler başlama düzeyi yoklama oturumları, öğretim oturumları, toplu yoklama oturumları ve izleme oturumları olmak üzere dört başlıkta gösterilmiştir. Grafiğin yatay ekseni oturum sayısını, düşey ekseni öğrencilerin doğru cevap yüzdelerini göstermektedir. İzleyen bölümde araştırmanın öğretim öncesi, öğretim zamanı ve öğretim sonrası öğrenci performanslarına yönelik bilgilere ve grafiksel verilere yer verilmiştir.

\section{Saat Becerisi Başlama Düzeyi Oturumları Bulguları}

Mert, buçuk saatleri söyleme becerisi için üç oturum üst üste \%0 oranında performans göstermiştir. Emir, buçuk saatleri söyleme becerisi için üç oturum üst üste $\% 0$ oranında performans göstermiştir. Ayşe, buçuk saatleri söyleme becerisi için üç oturum üst üste $\% 0$ oranında performans göstermiştir. 


\section{Saat Becerisi Öğretim Oturumları Bulgulart}

Mert, buçuk saatleri söyleme becerisinin birinci öğretim oturumunda $\% 75$, ikinci öğretim oturumunda $\% 75$, üçüncü öğretim oturumunda $\% 100$, dördüncü öğretim oturumunda $\% 100$ ve beşinci öğretim oturumunda \%100 oranında doğru tepkide bulunmuştur. Mert; beş öğretim oturumunun üçüncü, dördüncü ve beşinci oturumlarında buçuk saatleri söyleme becerisi için üst üste üç oturum ölçütü karşılayacak düzeyde performans göstermiştir.

Emir, buçuk saatleri söyleme becerisinin birinci öğretim oturumunda \%42, ikinci öğretim oturumunda $\% 58$, üçüncü öğretim oturumunda $\% 83$, dördüncü öğretim oturumunda $\% 75$, beşinci öğretim oturumunda, $\% 83$, altıncı öğretim oturumunda $\% 58$, yedinci öğretim oturumunda $\% 75$, sekizinci öğretim oturumunda $\% 100$, dokuzuncu öğretim oturumunda $\% 83$ ve onuncu öğretim oturumunda $\% 92$ oranında doğru tepkide bulunmuştur. Emir; on öğretim oturumunun sekizinci, dokuzuncu ve onuncu oturumlarında buçuk saatleri söyleme becerisi için üst üste üç oturum ölçütü karşılayacak düzeyde performans göstermiştir.

Ayșe, buçuk saatleri söyleme becerisinin birinci öğretim oturumunda $\% 42$, ikinci öğretim oturumunda $\% 75$, üçüncü öğretim oturumunda $\% 75$, dördüncü öğretim oturumunda $\% 83$, beşinci öğretim oturumunda $\% 92$ ve altınc öğretim oturumunda $\% 100$ oranında doğru tepkide bulunmuştur. Ayșe; altı öğretim oturumunun dördüncü, beşinci ve altıncı oturumlarında buçuk saatleri söyleme becerisi için üst üste üç oturum ölçütü karşllayacak düzeyde performans göstermiştir.

\section{Para Becerisi Başlama Düzeyi Oturumları Bulgulart}

Mert, aynı madeni paraların toplam miktarını söyleme becerisi için üç oturum üst üste $\% 0$ oranında performans göstermiştir. Emir, aynı madeni paraların toplam miktarını söyleme becerisi için üç oturum üst üste $\% 0$ oranında performans göstermiştir. Ayşe, aynı madeni paraların toplam miktarını söyleme becerisi için üç oturum üst üste $\% 0$ oranında performans göstermiştir.

\section{Para Becerisi Öğretim Oturumları Bulgulart}

Mert, aynı madeni paraların toplam miktarını söyleme becerisinin birinci öğretim oturumunda $\% 100$, ikinci öğretim oturumunda $\% 100$ ve üçüncü öğretim oturumunda da $\% 100$ oranında doğru tepkide bulunmuştur. Mert; aynı madeni paraların toplam miktarını söyleme becerisi için üst üste üç oturum ölçütü karşılayacak düzeyde performans göstermiştir.

Emir, aynı madeni paraların toplam miktarını söyleme becerisinin birinci öğretim oturumunda \%33, ikinci öğretim oturumunda $\% 0$, üçüncü öğretim oturumunda $\% 66$, dördüncü öğretim oturumunda $\% 33$, beşinci öğretim oturumunda $\% 100$, altıncı öğretim oturumunda $\% 100$ ve yedinci öğretim oturumunda da $\% 100$ oranında doğru tepkide bulunmuștur. Emir; yedi öğretim oturumunun beşinci, altıncı ve yedinci oturumlarında aynı madeni paraların toplam miktarını söyleme becerisi için üst üste üç oturum ölçütü karşılayacak düzeyde performans göstermiştir.

Ayşe, aynı madeni paraların toplam miktarını söyleme becerisinin birinci öğretim oturumunda \%33, ikinci ögretim oturumunda $\% 66$, üçüncü öğretim oturumunda $\% 100$, dördüncü öğretim oturumunda $\% 100$ ve beşinci öğretim oturumunda \%100 oranında doğru tepkide bulunmuştur. Ayşe; beş öğretim oturumunun üçüncü, dördüncü ve beşinci oturumlarında aynı madeni paraların toplam miktarını söyleme becerisi için üst üste üç oturum ölçütü karşılayacak düzeyde performans göstermiştir.

\section{Kesir Becerisi Başlama Düzeyi Oturumları Bulguları}

Mert, kesirleri söyleme becerisi için üç oturum üst üste $\% 0$ oranında performans göstermiş̧tir. Emir, kesirleri söyleme becerisi için üç oturum üst üste $\% 0$ oranında performans göstermiştir. Ayşe, kesirleri söyleme becerisi için üç oturum üst üste $\% 0$ oranında performans göstermiştir.

\section{Kesir Becerisi Öğretim Oturumları Bulguları}

Mert, kesirleri söyleme becerisinin birinci öğretim oturumunda \%60, ikinci öğretim oturumunda \%80, üçüncü öğretim oturumunda $\% 100$, dördüncü öğretim oturumunda $\% 100$ ve beşinci öğretim oturumunda $\% 100$ oranında doğru tepkide bulunmuştur. Mert; beş öğretim oturumunun üçüncü, dördüncü ve beşinci oturumlarında kesirleri söyleme becerisi için üst üste üç oturum ölçütü karşllayacak düzeyde performans göstermiştir.

Emir, kesirleri söyleme becerisinin birinci öğretim oturumunda \%0, ikinci öğretim oturumunda \%20, üçüncü öğretim oturumunda $\% 40$, dördüncü öğretim oturumunda $\% 60$, beşinci öğretim oturumunda $\% 100$, altınc1 

BECERILERININ ÖĞRETIMININ ETKILILIĞĞI

öğretim oturumunda \%100 ve yedinci öğretim oturumunda da \%100 oranında doğru tepkide bulunmuştur. Emir; yedi öğretim oturumunun beşinci, altıncı ve yedinci oturumlarında kesirleri söyleme becerisi için üst üste üç oturum ölçütü karşılayacak düzeyde performans göstermiştir.

Ayşe, kesirleri söyleme becerisinin birinci öğretim oturumunda \%60, ikinci öğretim oturumunda \%80, üçüncü öğretim oturumunda $\% 100$, dördüncü öğretim oturumunda $\% 100$ ve beşinci öğretim oturumunda da $\% 100$ oranında doğru tepkide bulunmuştur. Ayşe; kesirleri söyleme becerisi için üst üste üç oturum ölçütü karşılayacak düzeyde performans göstermiştir.

\section{İzlemeye İlişkin Bulgular}

İzleme verileri, her üç beceride hedeflenen ölçüte ulaşıldıktan beș, yedi ve on iki gün sonra toplanmıștır. İzleme verileri, her öğrenci ve beceri için ayrı ayrı toplanmıştır. Mert, Emir ve Ayşe’ye ilişkin izleme verileri aşağıda detaylı bir şekilde açıklanmıştır.

\section{Saat Becerisi İzleme Oturumları Bulguları}

Mert'in kazandığı saat becerisini \%100 oranında koruduğu görülmektedir. Emir'in kazandığ1 saat becerisini ortalama \%86 oranında koruduğu görülmektedir. Ayşe'nin kazandığı saat becerisini ortalama \%89 oranında koruduğu görülmektedir.

\section{Para Becerisi İzleme Oturumlart Bulgulart}

Mert'in kazandığı para becerisini \%100 oranında koruduğu görülmektedir. Emir'in kazandığı para becerisini $\% 100$ oranında koruduğu görülmektedir. Ayşe'nin kazandığı para becerisini \%100 oranında koruduğu görülmektedir.

\section{Kesir Becerisi İzleme Oturumları Bulgulart}

Mert'in kazandığ 1 kesir becerisini \%100 oranında koruduğu görülmektedir. Emir'in kazandığı kesir becerisini \%100 oranında koruduğu görülmektedir. Ayşe'nin kazandığı kesir becerisini \%100 oranında koruduğu görülmektedir.

\section{Genellemeye İlişkin Bulgular}

Araştırmanın genelleme verileri ön test-son test modeli kullanılarak toplanmıştır. Ön test verileri başlama düzeyi yoklama oturumlarından hemen sonra, son test verileri ise öğretim oturumları bittikten hemen sonra düzenlenen genelleme oturumlarında toplanmıştır. Öğrencilerle öğretim oturumlarından farklı olarak saat becerisine yönelik duvar saati yerine masa saati, para becerisine yönelik gerçek paralar yerine para resimlerinin olduğu genelleme materyali ve kesir becerisine yönelik daire şekli yerine dikdörtgen şeklinin olduğu kesir genelleme materyali kullanılmıştır. Genelleme bulgularına bakıldığında: Mert'in aynı madeni paraların toplam miktarını söyleme becerisine ilişkin ön test verisi $\% 0$, son test verisi $\% 100$; buçuk saatleri söyleme becerisine ilişkin ön test verisi $\% 0$, son test verisi $\% 100$; kesirleri söyleme becerisine ilişkin ön test verisi $\% 0$, son test verisi $\% 100$ 'dür. Emir'in aynı madeni paraların toplam miktarını söyleme becerisine ilişkin ön test verisi \%0, son test verisi \%100; buçuk saatleri söyleme becerisine ilişkin ön test verisi \%0, son test verisi \%90; kesirleri söyleme becerisine ilişkin ön test verisi \%0, son test verisi \%100'dür. Ayşe'nin aynı madeni paraların toplam miktarını söyleme becerisine ilişkin ön test verisi $\% 0$, son test verisi $\% 100$; buçuk saatleri söyleme becerisine ilişkin ön test verisi $\% 0$, son test verisi $\% 90$; kesirleri söyleme becerisine ilişkin ön test verisi $\% 0$, son test verisi $\% 100$ 'dür. Araştırmanın genelleme bulgularında; öğrencilerin ön-test ve son-test verileri, öğrendikleri becerileri farklı araçgereçlere yüksek bir doğruluk düzeyinde genelleyebildiklerini göstermektedir. Mert'e, Emir'e ve Ayşe'ye ilişkin genelleme verileri Grafik 4, Grafik 5 ve Grafik 6'da gösterilmiştir. 

BECERILERININ ÖĞRETIMININ ETKILILILIĞİ

\section{Grafik 1}

Mert’in Doğrudan Öğretim Yöntemiyle Işslevsel Matematik Becerilerinin Öğretiminin Etkililiğine İlişkin Bulgular

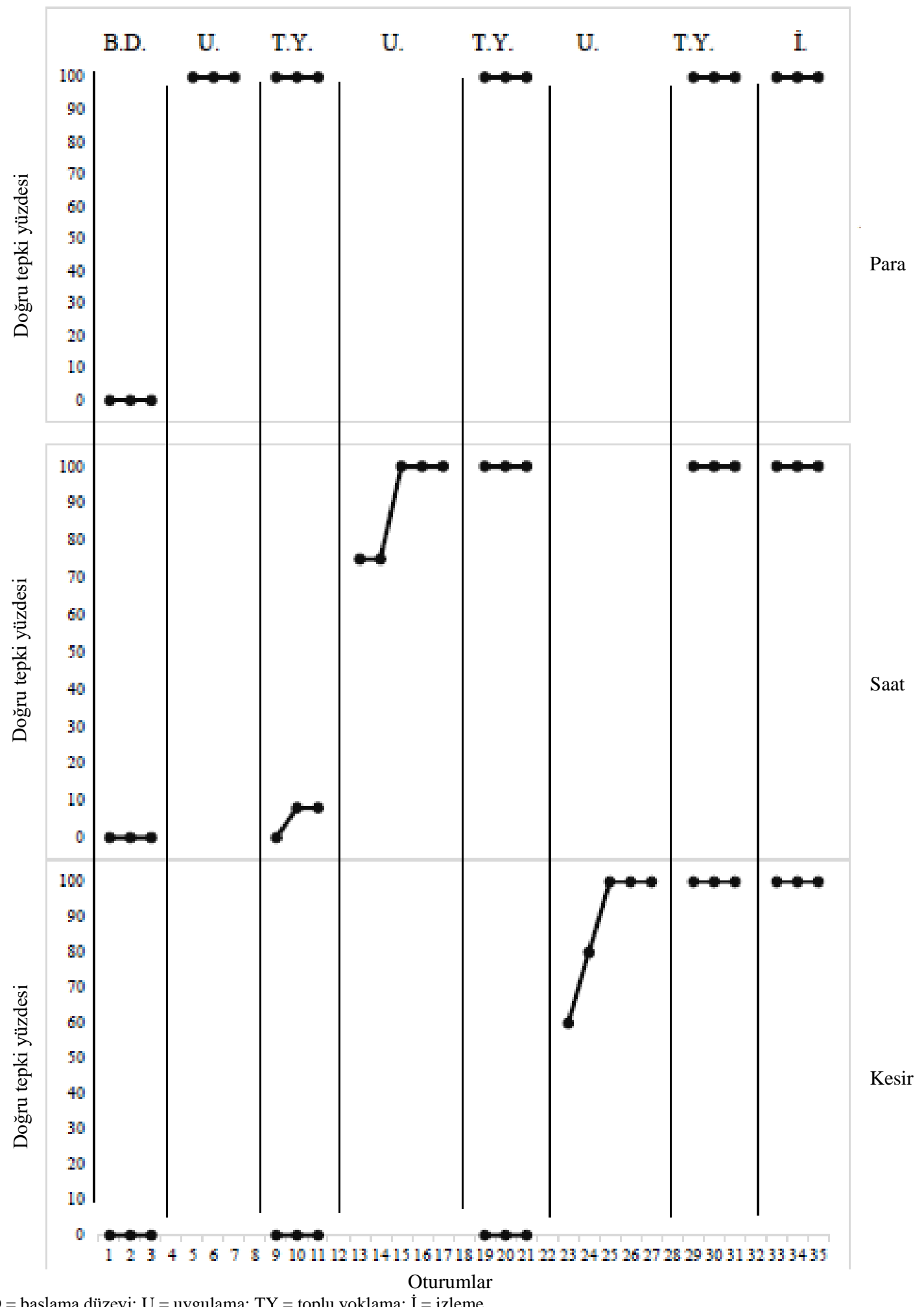

Not: $\mathrm{BD}=$ başlama düzeyi; $\mathrm{U}=$ uygulama; $\mathrm{TY}$ = toplu yoklama; $\mathrm{I}$ = izleme 

BECERILERININ ÖĞRETIMININ ETKILILILIĞİ

\section{Grafik 2}

Emir’in Doğrudan Öğretim Yöntemiyle Işslevsel Matematik Becerilerinin Öğretiminin Etkililiğine İlişkin Bulgular

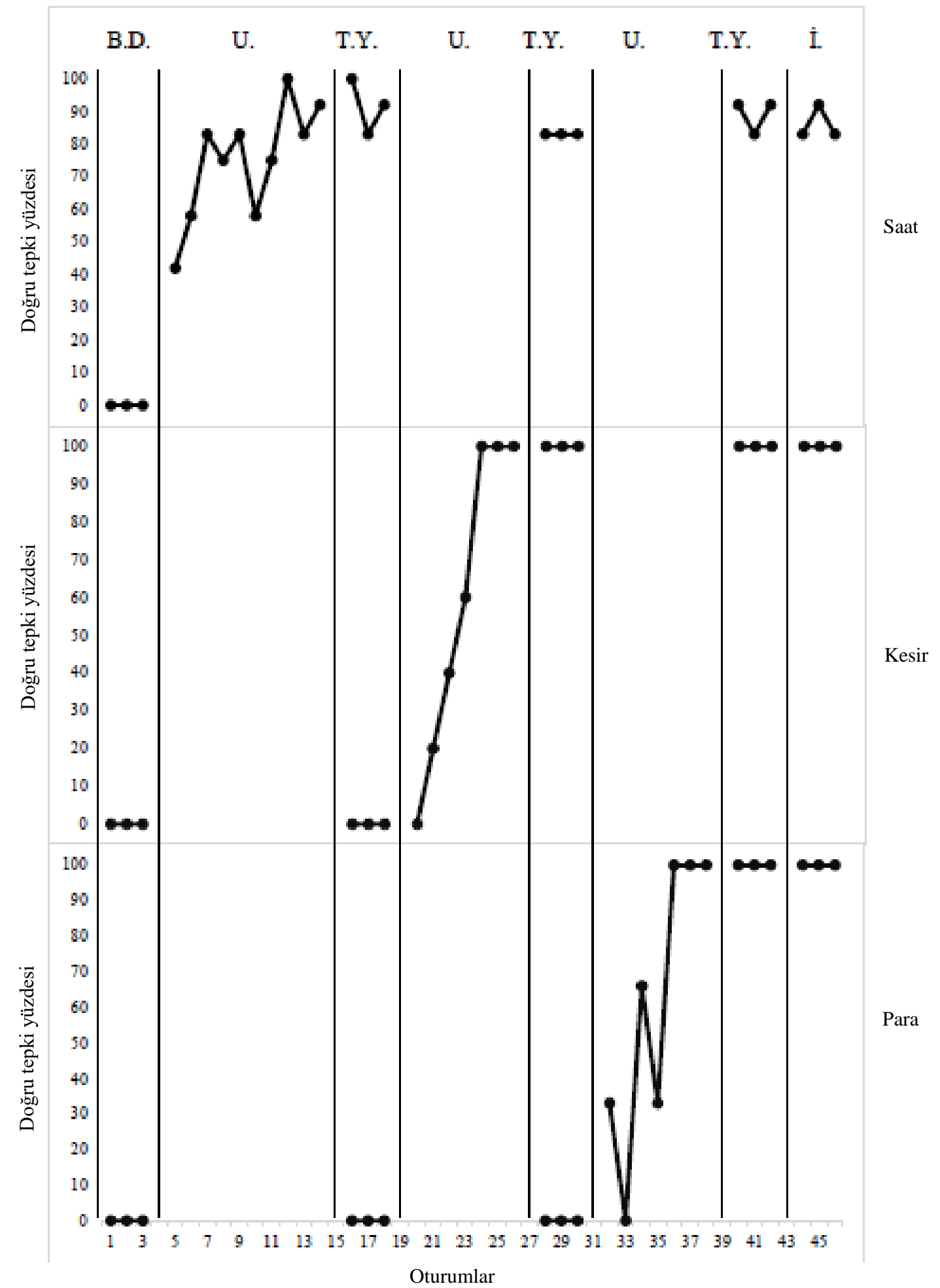

Not: $\mathrm{BD}=$ başlama düzeyi; $\mathrm{U}=$ uygulama; $\mathrm{TY}$ = toplu yoklama; $\dot{\mathrm{I}}=$ izleme. 

BECERILERININ ÖĞRETIMININ ETKILILILIĞI

\section{Grafik 3}

Ayşe’nin Doğrudan Öğretim Yöntemiyle İşlevsel Matematik Becerilerinin Öğretiminin Etkililiğine İlişkin Bulgular

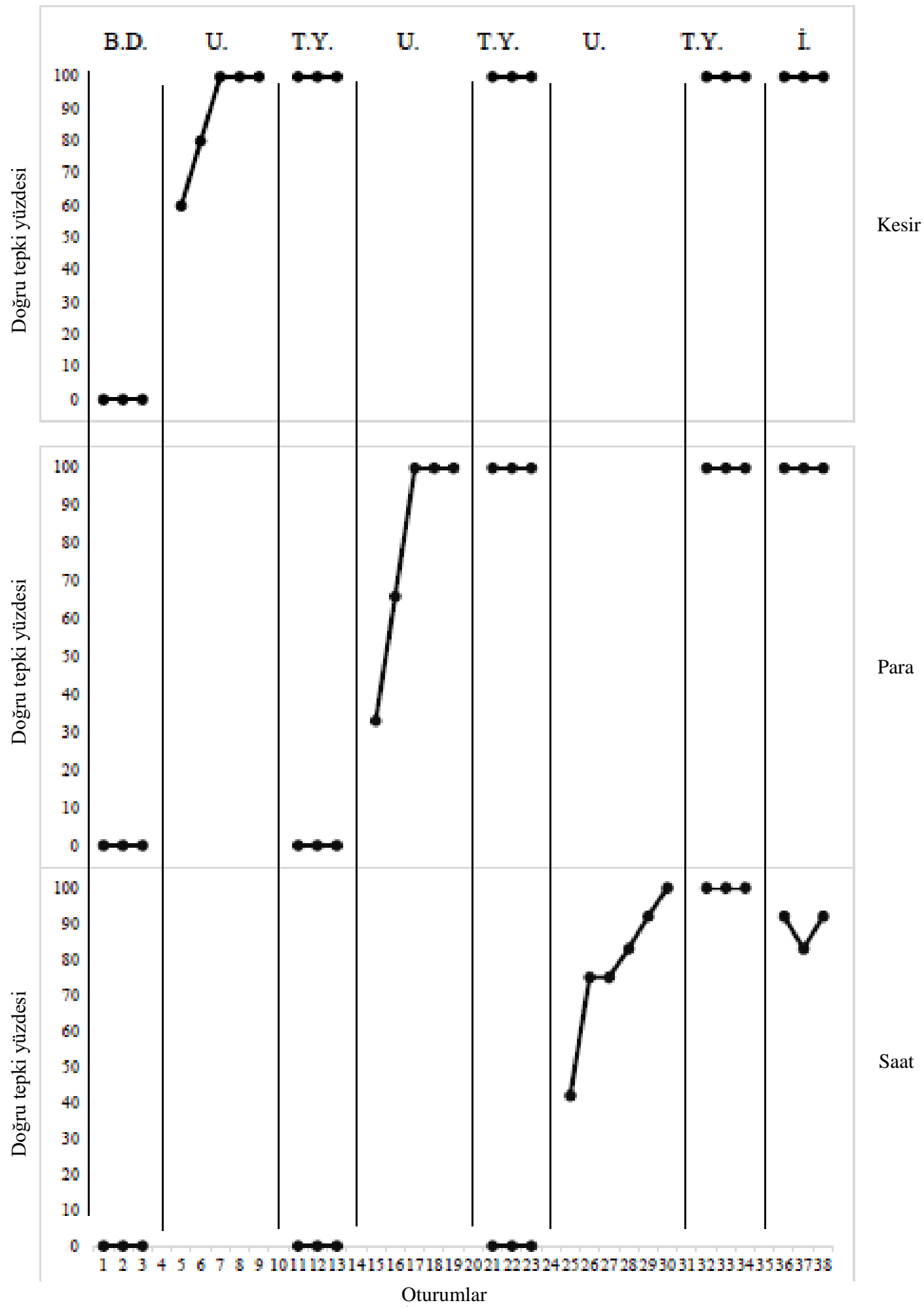

Not: $\mathrm{BD}$ = başlama düzeyi; $\mathrm{U}=$ uygulama; $\mathrm{TY}=$ toplu yoklama; $\dot{\mathrm{I}}=$ izleme. 

BECERILERININ ÖĞRETIMININ ETKILILILIĞI

\section{Grafik 4}

Mert'in Aynı Madeni Paraların Toplam Miktarını Söyleme, Buçuk Saatleri Söyleme ve Kesirleri Söyleme Becerisine Illişkin Genelleme Verileri

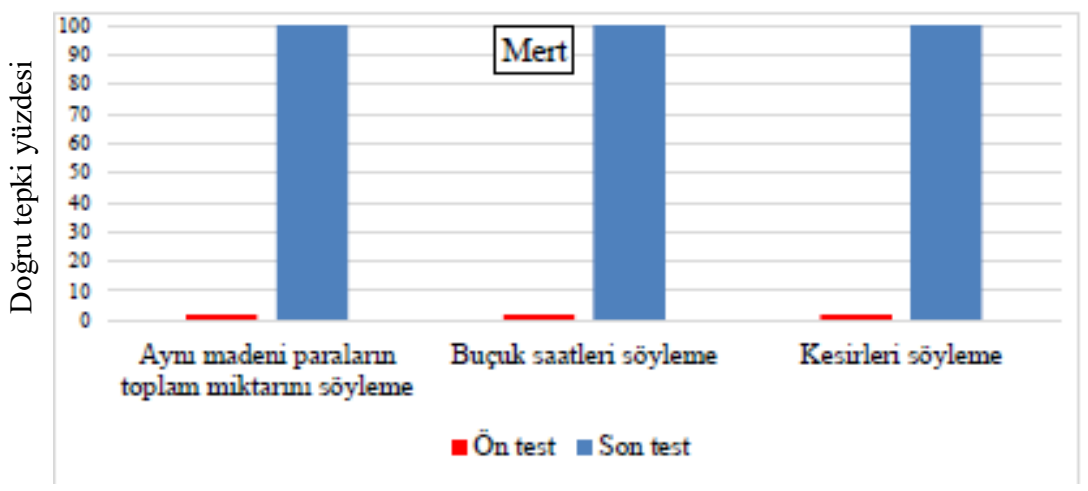

\section{Grafik 5}

Emir'in Aynı Madeni Paraların Toplam Miktarını Söyleme, Buçuk Saatleri Söyleme ve Kesirleri Söyleme Becerisine İlişkin Genelleme Verileri

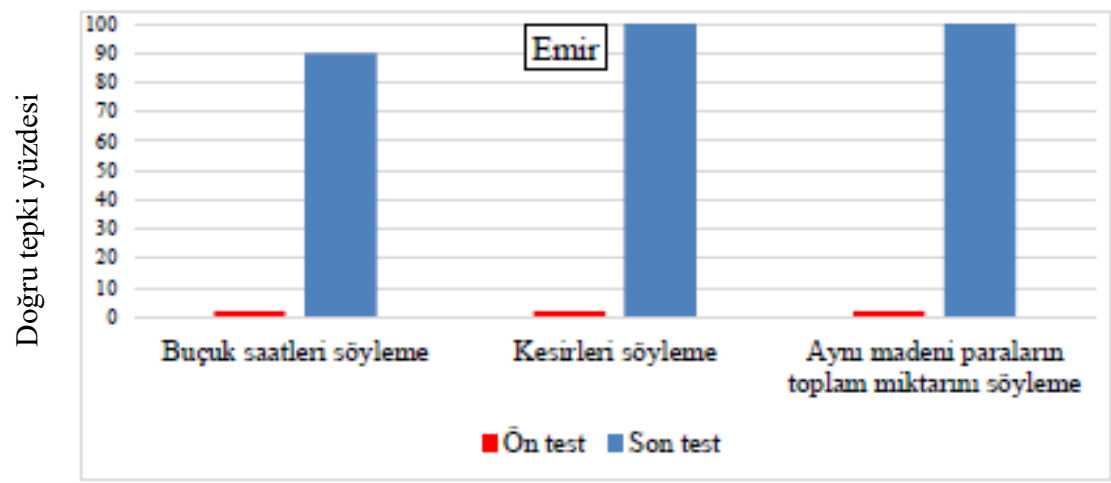

\section{Grafik 6}

Ayşe’nin Aynı Madeni Paraların Toplam Miktarını Söyleme, Buçuk Saatleri Söyleme ve Kesirleri Söyleme Becerisine İlişkin Genelleme Verileri

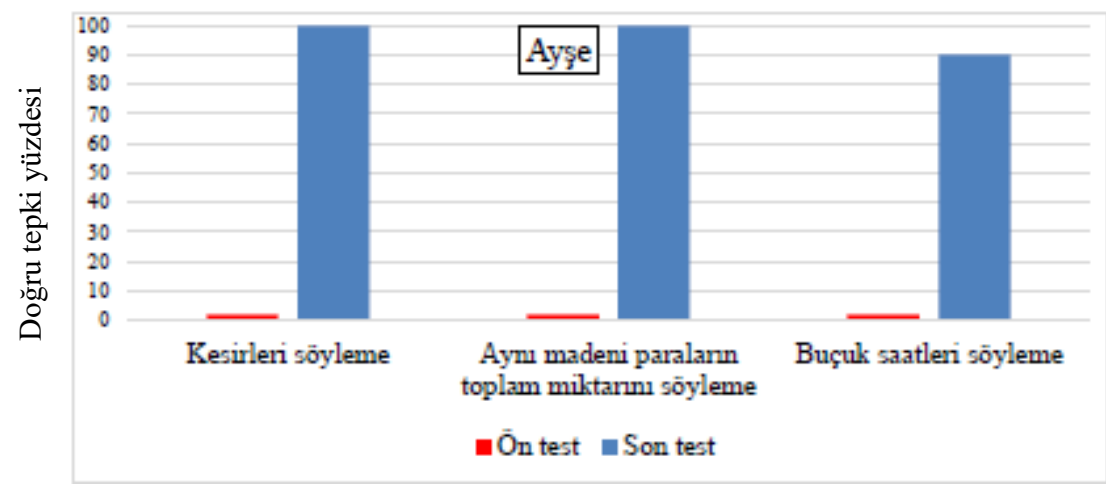



BECERILERININ ÖĞRETIMININ ETKILILİIĞI

\section{Sosyal Geçerlik Bulguları}

Sosyal Geçerlik Veri Toplama Formu iki sınıf öğretmeni tarafından cevaplanmıștır. Araştırmaya katılan öğretmenler doğrudan öğretim yöntemiyle işlevsel matematik becerilerinin öğretimi konusunda genel olarak olumlu görüşte bulunmuşlardır. Öğretmenler; bu çalışmaya katılmaktan memnun olduklarını, işlevsel matematik becerilerinin öğrenciler açısından önemli olduğunu ve araştırma bitiminde öğrencilerde bu becerilerin gelişimine yönelik bir farklılık olduğunu belirtmiş̧lerdir. İşlevsel matematik becerilerinin öğrencilerin akademik, günlük ve bağımsız yaşam becerilerin gelişimine katkı sağlayacağını ifade etmişlerdir. Öğretmenler; doğrudan öğretim yöntemini sınıftaki uygulamalarda kullanmayı ve başka öğretmenlere önermeyi düşündüklerini belirtmişlerdir. Öğretmenlerden biri, öğrencilerin araştırmada öğrendiği becerileri sınıftaki çalışmalarında, ödevlerinde ve günlük yaşamlarında kullandıklarını gözlemlediğini, diğer öğretmen ise gözlemlemediğini belirtmiştir. Öğretmenlerden biri, işlevsel matematik becerilerinin öğrencilerin derslere uyumunu arttırdığını, diğer öğretmen ise işlevsel matematik becerilerinin öğrencisinin derslere uyumunu arttırmadığını ifade etmiştir. Öğretmenlere araştırma sonunda öğrencilerinde gördükleri değişiklikler sorulduğunda; bir öğretmen, işlevsel matematik becerilerinin sınıfta işlenmeye başlandığında öğrencilerin derslere katılımda daha istekli olduklarını ifade etmiştir. Diğer öğretmen ise öğrencide bir değişiklik görmediğini ve öğrencinin genel olarak tüm derslere ilgisiz olduğunu ifade etmiştir.

\section{Güvenirlik Bulguları}

Katılımcılardan her beceri için ayrı ayrı gözlemciler arası güvenirlik verisi toplanmıştır. Mert ile çalışılan becerilere ilişkin gözlemciler arası güvenirlik katsayısı en az $\% 98$, en çok $\% 100$ olarak bulunmuştur. Emir ile çalışılan becerilere iliş̧in gözlemciler arası güvenirlik katsayısı en az $\% 98$, en çok $\% 100$ olarak bulunmuştur. Ayşe ile çalışılan becerilere ilişkin gözlemciler arası güvenirlik katsayısı en az \%98, en çok \%100 düzeyinde bulunmuştur.

Katılımcıların her beceri ile yapılan uygulama için ayrı ayrı uygulama güvenirliği verisi toplanmıştır. Mert ile çalışılan becerilere ilişkin uygulama güvenirliği katsayısı en az \%96, en çok \%100 olarak bulunmuştur. Emir ile çalışılan becerilere ilişkin uygulama güvenirlik katsayısı en az $\% 98$, en çok $\% 100$ olarak bulunmuştur. Ayşe ile çalışılan becerilere ilişkin uygulama güvenirlik katsayısı en az \%98, en çok \%100 düzeyinde bulunmuştur.

\section{Tartışma}

Araştırmadan elde edilen bulgulara göre; (a) bu araştırmada kullanılan doğrudan öğretim yönteminin gelişimsel yetersizliği olan öğrencilere işlevsel matematik becerilerinin öğretiminde etkili olduğu, (b) öğrencilerin, ögretim bittikten beş, yedi ve on iki gün sonra gerçekleştirilen izleme oturumlarında öğrendikleri bu becerileri koruyabildikleri, (c) öğrencilerin, öğretim bittikten sonra düzenlenen genelleme oturumlarında öğrendikleri bu becerileri farklı araç-gereçlere genelleyebildikleri ve (d) araştırmaya katılan öğrencilerin sinıf öğretmenlerinin araştırmanın sosyal geçerliğine ilişkin genel anlamda olumlu görüş bildirdikleri görülmüştür.

Araştırmanın ilk bulgusu, işlevsel matematik becerilerinin öğretiminde doğrudan öğretim yönteminin etkili olduğunu göstermektedir. Doğrudan öğretim yöntemiyle işlevsel matematik becerilerinin öğretiminin etkililiğini inceleyen diğer araştırmaların elde ettiği bulgularla benzerlik gösterdiği görülmektedir (Birkan, 2012; Dağseven, 2001; Flores \& Kaylor, 2007; Lowe \& Cuvo, 1976; Tufan vd., 2020). Araştırmaya katılan tüm öğrencilerin öğretimi gerçekleştirilen işlevsel matematik becerilerine ilişkin öğretim öncesi düzenlenen başlama düzeyi oturumlarındaki düşük performanslarının, öğretim sonrası düzenlenen günlük yoklama ve toplu yoklama oturumlarında anlamlı bir şekilde arttığı görülmektedir. Öğrenciler, öğretim sonunda işlevsel matematik becerilerini bağımsız olarak gerçekleştirebilir seviyeye ulaşmışlardır.

Öğretim aşamasında; Mert ve Ayşe'nin doğru tepki yüzdelerinin aksine Emir'in saat ve para becerilerine ilişkin doğru tepki yüzdelerinde düzenli bir artış yerine inişli çıkışlı bir performans görülmektedir. Emir'in saat becerisine yönelik özellikle altıncı öğretim oturumunda ani bir düşüş göze çarpmaktadır. Bunun nedeni, Emir altıncı ögretim oturumunda göstermesi ve okuması istenen buçuk saati, akrep ve yelkovanını yanlış ayarladığ 1 için yanlış okumuş̧ur. Emir, 12:30'u kısa ve uzun kolun (akrep ve yelkovan) pozisyonu itibariyle 6:30 ile karıştırmış̧ır. 5:30 ile 7:30'u da 6:30 ile sıklıkla karıştırmıştır. Belirtilen buçuk saatlerde; hem kısa ve uzun kolun birbirlerine yakın pozisyonda olması hem de saatin sağ yarısında kısa kolun üstünde kalan saat söylenirken, sol yarısında ise kısa kolun altında kalan saatin söylenmesinin de öğrencinin bu saatleri birbirleriyle karıştırmasına neden olduğu düşünülmektedir. 

BECERILERININ ÖĞRETIMININ ETKILILİĞI

İlgili buçuk saatin yanlış gösterilmesi ve/veya okunamaması kayıt formuna “_” olarak işaretlenmiştir. Belirtilen bu saatlerin aynı oturumda birbirleriyle karıştırılması Emir'in performansında ani düşüş yaşamasına sebep olmuştur. Emir öğrenim sürecinde bu saatler arasındaki farka alıştıktan iki oturum sonra (8. oturum) \%100 performansa ulaşmıştır. Emir beceriyi \%100 doğrulukla gerçekleştirdikten sonra 9 . ve 10. öğretim oturumlarında da ölçütü karş1lar düzeyde performans göstermeye devam etmiştir. Emir'in para becerisine yönelik ikinci ve dördüncü ögrretim oturumlarında ani düşüş yaşamasının sebebi ise paraları ayırırken sayma işlemini ritmik sayma temposuyla yapmış olmasıdır. Buna bağlı olarak paraları ayırırken sayma işlemini eşzamanlı yapmadığı için paraları ya eksik ya da fazla saymış ve toplam miktarı yanlış söylemiştir. Emir ikinci oturumda üç farklı para sayma becerisini, üçüncü oturumda yirmi beş kuruşları, dördüncü oturumda da beş ve yirmi beşer kuruşları bu hata nedeniyle yanlış saydığ 1 için paraların toplam miktarını söyleyememiş ve kayıt formuna beceri "_" olarak işaretlenmiştir. Emir'e paraları ayırarak sayarken sayma işlemini eşzamanlı olarak yapması gerektiği fark ettirildikten sonra diğer oturumlarda beceriyi \%100 doğrulukla gerçekleştirmiştir.

Araştırma bulgularına göre; üç öğrencinin de en fazla hata yaptığı ve en uzun sürede öğrendiği beceri buçuk saatleri söyleme becerisidir. Elde edilen bu bulgunun saat söyleme becerisine ilişkin diğer araştırmaların elde ettiği bulgularla benzerlik gösterdiği görülmektedir (Andersson, 2008; Burny vd., 2011; Desoete, 2009). Tam saatleri söyleme becerisinde saatin kısa kolu herhangi bir saati net bir şekilde gösterirken, buçuk saatleri söyleme becerisinde saatin kısa kolu ardışı iki saatin arasını göstermektedir. Bu yüzden öğrencilerin buçuk saatleri söyleme becerisini öğrenmekte zorlandıkları düşünülmektedir. Saatin sağ yarısında kısa kolun üstünde kalan saat söylenirken, saatin sol yarısında kısa kolun altında kalan saatin söylenmesinin de öğrencilerin buçuk saatleri söyleme becerisini öğrenmelerini zorlaştırdığı düşünülmektedir. Sonuç olarak; öğrencilerin ardışık iki saatten önceki saati mi yoksa sonraki saati mi söyleyecekleri konusunda zorlandıkları gözlemlenmiştir. Yapılan araştırmalar; öğrencilere sadece saati söyleme, para miktarını hesaplama ve kesirleri söyleme becerilerini öğretmeyi değil, aynı zamanda bu becerileri akıcı bir biçimde kullanmayı, öğretim sona erdikten sonra da devam ettirilmesi gerektiğini vurgulamaktadır (Browder \& Grasso, 1999). Bu nedenle araştırmanın ikinci bulgusu, öğretim bittikten beş, yedi ve on iki gün sonra gerçekleştirilen izleme oturumları, deneklerin öğretimi yapılan buçuk saatleri söyleme, aynı madeni paraların toplam miktarını söyleme ve kesirleri söyleme becerilerini koruyabildiklerini ve öğrenilen becerilerin kalıcı olduğunu göstermektedir.

Yapılan araştırmalar; öğrencilere sadece saati söyleme, para miktarını hesaplama ve kesirleri söyleme becerilerini öğretmeyi değil, aynı zamanda bu becerileri akıcı bir biçimde kullanmayı, öğretim sona erdikten sonra da devam ettirilmesi gerektiğini vurgulamaktadır (Browder \& Grasso, 1999). Bu nedenle araştırmanın ikinci bulgusu olan ve öğretim bittikten beş, yedi ve on iki gün sonra gerçekleştirilen izleme oturumları, deneklerin öğretimi yapılan buçuk saatleri söyleme, aynı madeni paraların toplam miktarını söyleme ve kesirleri söyleme becerilerini koruyabildiklerini ve öğrenilen becerilerin kalıcı olduğunu göstermektedir. Araştırmanın izleme bulgularında; gelişimsel yetersizliği olan öğrencilere doğrudan öğretim yöntemiyle öğretimi yapılan buçuk saatleri söyleme, aynı madeni paraların toplam miktarını söyleme ve kesirleri söyleme becerilerinin kalıcı olduğu ve daha önce yapılan araştırma bulgularıyla benzerlik gösterdiği görülmektedir (Birkan, 2012; Dağseven, 2001; Flores \& Kaylor, 2007; Lowe \& Cuvo, 1976; Tufan vd., 2020).

Araştırmanın üçüncü bulgusu olan genelleme bulgularında, öğrencilerin ön-test ve son-test verileri, öğrendikleri becerileri farklı araç-gereçlere yüksek bir doğruluk düzeyinde genelleyebildiklerini göstermektedir. $\mathrm{Bu}$ nedenle araştırma sonuçlarının alanyazına yeni bir katkı sağlayacağı düşünülmektedir. Öğrencinin bir eğitim ortamında sergilediği beceriyi devam ettiği diğer eğitim ortamında da sergilemesi önemli bir unsurdur. Öğrenciler, araştırma/rehabilitasyon merkezinde bireysel olarak yapılan derslerde edinmiş olduğu performansını okulunda da sergiliyor olması, akran ve öğretmen kabulünü artıracaktır.

Araştırmanın son bulgusunda ise araştırmaya katılan öğrencilerin sınıf öğretmenlerinin; buçuk saatleri söyleme, aynı madeni paraların toplam miktarını söyleme ve kesirleri söyleme becerisinin doğrudan öğretim yöntemiyle öğretiminin yapılmasına ilişkin görüşlerinin genel anlamda olumlu olduğudur. Ancak bir sınıf öğretmeni çalışmanın öğrenci üzerindeki çıktılarına yönelik olumsuz görüş bildirmiştir. İlgili öğrencinin (Mert) 4. sınıf olmasına rağmen okula yurt dışındaki bir okuldan bir buçuk yıl önce nakil gelmiş olması, geldiği okulda İngilizce eğitim almış olması ve yeni sınıfında sosyal uyum sorunu yaşıyor olması sınıf öğretmeninin olumsuz görüşlerine neden olarak gösterilebilir. Ayrıca çalışmanın ilgili öğrenciye ait grafiklerinden de anlaşılacağı üzere, öğrencinin bireysel çalışma performansı ile sınıftaki çalışma performansı arasındaki farkın da bu sebeplerden kaynaklandığı düşünülmektedir. 

BECERILERININ ÖĞRETIMININ ETKILILİĞİ

Araştırmada edinim, izleme ve genellemeye ilişkin bulguların yüksek doğruluk düzeyinde olmasına rağmen, çalışmada göz önünde bulundurulması gereken bazı sınırlılıklar bulunmaktadır. Birincisi, bu araştırma, gelişimsel yetersizliği olan ve destek eğitim odasında bireysel eğitim almakta olan üç öğrenci ile tek denekli bir araştırma olarak gerçekleştirilmiştir. Bu sınırlılık gelişimsel yetersizlik gösteren öğrencilerin genellenebilirliğini sınırlamaktadır. Benzer bir çalışmanın daha fazla öğrenci ile gerçekleştirilmesi çalışma sonuçlarının genellenebilirliğine olumlu katkı sağlayacaktır. İkinci sınırlılık ise araştırmada ortam ve zaman genellemesine yönelik verilerin toplanmamış olmasıdır. Yapılan çalışmanın okul vaktinde ve market, bakkal gibi gerçek toplumsal ortamlar yerine sınıf içinde yapılandırılmış bir ortamda gerçekleştirilmiş olması edinilen becerilerin ortam ve zaman genellenebilirliğini olumsuz yönde etkilemektedir. Üçüncü sınırlılık ise çalışmada kullanılan materyallerin analog saatler, madeni paralar ve basit kesirler ile sınırlı olmasıdır.

$\mathrm{Bu}$ araştırmanın şu açılardan alanyazına katkı sağlayacağı düşünülmektedir: (1) Araştırma bulguları doğrudan öğretim yöntemiyle işlevsel matematik beceri ve kavramların öğretiminin gelişimsel yetersizlik gösteren öğrencilere buçuk saatleri söyleme, aynı madeni paraların toplam miktarını söyleme ve kesirleri söyleme becerilerinin öğretiminde ve öğretilen becerilerin kalıcılığının sağlanmasında etkili olduğunu ve kolaylıkla uygulanabileceğini gösterir niteliktedir. (2) İşlevsel matematik becerilerinin öğretiminin doğrudan öğretim yöntemiyle sunulmasının buçuk saatleri söyleme, aynı madeni paraların toplam miktarını söyleme ve kesirleri söyleme becerilerinin öğretiminde çeşitli avantajlar sağladığ becerilerin öğretimine kaynaklık edebileceği söylenebilir. (3) Çalışmada gözlemciler arası güvenirlik ve uygulama güvenirliği oldukça yüksek bulunmuştur. Bu yönüyle de alanyazına katkı sağlayacağı düşünülmektedir.

Araştırma bulguları, doğrudan öğretim yönteminin gelişimsel yetersizliği olan öğrencilere işlevsel matematik becerilerinin öğretiminde ve genellemesinde etkili olduğunu göstermektedir. Gelişimsel yetersizliği olan çocuğa sahip ailelere, sınıf öğretmenlerine ve özel eğitim öğretmenlerine işlevsel matematik becerilerinin öğretiminde doğrudan öğretim yöntemini kullanmaları önerilebilir. Gelişimsel yetersizliği olan öğrencilere yönelik hazırlanan öğretim programları doğrudan öğretim yöntemine göre hazırlanabilir.

İleri araştırmalar; kağıt paraların toplam miktarını söyleme, dijital saatleri söyleme, bileşik kesirleri söyleme, ağırlık ölçme, uzunluk ölçme, sıvıları ölçme gibi becerilerle gerçekleştirilebilir. İşlevsel matematik becerilerinin öğretiminin, farklı uygulamacılarla, farklı ortamlarda ve farklı öğretim yöntemiyle etkililiği araştırılabilir. İşlevsel matematik becerilerinin öğretimi, bireysel öğretim yerine küçük grup öğretimi şeklinde düzenlenerek doğrudan öğretim yönteminin grup öğretiminde etkililiği araştırılabilir.

\section{Yazarların Katkı Düzeyleri}

Çalışma, Dr. Öğr. Üyesi Oğuz Gürsel danışmalığında gerçekleştirilen Özer Akgün'ün yüksek lisans tez çalışmasından üretilmiştir. $\mathrm{Bu}$ nedenle çalışma konusu, araştırma deseni, verilerin analizi ve çalışmanın raporlanması iki yazar tarafından birlikte belirlenmiş ve gerçekleştirilmiştir. Verilerin toplanması ise Özer Akgün tarafından gerçekleştirilmiştir. 


\section{Kaynaklar}

Andersson, U. (2008). Mathematical competencies in children with different types of learning difficulties. Journal of Educational Psychology, 100(1), 48-66. https://doi.apa.org/record/2008-01796-004?doi=1

Birkan, B. (2012). Teaching, maintaining and generalizing time concepts for students with disabilities: How many sub-aims should be thought? Ilkögrretim Online, 11(3), 829-844. https://citeseerx.ist.psu.edu/viewdoc/download?doi=10.1.1.961.9478\&rep=rep1\&type=pdf

Borakove, L. S., \& Cuvo, A. J. (1977). Facilitative effects of coin displacement on teaching coin summation to mentally retarded adolescents. American Journal of Mental Deficiency, 81(4), 350-356.

Bottge, B. A., \& Hasselbring, T. S. (1993). A comparison of two approaches for teaching complex, authentic mathematics problems to adolescents in remedial math classes. Exceptional Children, 59(6), 556-511. https://doi.org/10.1177/001440299305900608

Bottge, B. A., Heinrichs, M., Mehta, Z. D., \& Hung,Y. H. (2002). Weighing the benefits of anchored math instruction for students with disabilities in general education classes. Journal of Special Education, 35(4), 186-200. https://doi.org/10.1177/002246690203500401

Browder, D. M., \& Grasso, E. (1999). Teaching money skills to individuals with mental retardation: A research review with practical applications. Remedial and Special Education, 20(5), 297-308. https://doi.org/10.1177/074193259902000506

Buğan, M. G. (1999). Yetişkin zihin engelli kadınların günlük yaşam becerilerini gerçekleştirme durumlarının belirlenmesi [Identify mentally retarded women's acqusition of daily living skills] (Tez Numarası: 92050) [Yüksek lisans tezi, Anadolu Üniversitesi]. Yükseköğretim Kurulu Ulusal Tez Merkezi.

Burns, M. K., \& Ysseldyke, J. E. (2009). Reported prevalence of evidence-based instructional practices in special education. The Journal of Special Education, 43(1), 3-11. https://doi.org/10.1177/0022466908315563

Burny, E., Valcke, M., \& Desoete, A. (2011). Clock reading: An underestimated topic in children with mathematics difficulties. Journal of Learning Disabilities, 45(4), 351-360. https://doi.org/10.1177/0022219411407773

Burton, C. E., Anderson, D. H., Prater, M. A., \& Dyches, T. T. (2013). Video self-modeling on an iPad to teach functional math skills to adolescents with autism and intellectual disability. Focus on Autism and Other Developmental Disabilities, 28(2), 67-77. https://doi.org/10.1177/1088357613478829

Butler, F. M., Miller, S. P., Crehan, K., Babbitt, B., \& Pierce, T. (2003). Fraction instruction for students with mathematics disabilities: Comparing two teaching sequences. Learning Disabilities Research \& Practice, 18(2), 99-111. https://doi.org/10.1111/1540-5826.00066

Dağseven, D. (2001). Zihinsel engelli öğrencilere temel toplama ve saat okuma becerilerinin kazandırlması, sürekliliğ $i$ ve genellenebilirliğinde, doğrudan ve basamaklandırılmış öğretim yaklaşımlarına göre hazırlanan öğretim materyalinin farklllaşan etkililiği [The effectiveness of instructional materials that were designed according to direct instruction and interactive unit in acquization, maintanence and generelization of addition and telling time skills in students with mental retardation] (Tez Numaras1: 108833) [Yüksek lisans tezi, Gazi Üniversitesi]. Yükseköğretim Kurulu Ulusal Tez Merkezi.

Denny, P. J., \& Test, D. W. (1995). Using the one-more-than technique to teach money counting to individuals with moderate mental retardation. Education and Treatment of Children, 18(4), 422-433. https://www.jstor.org/stable/42899427

Desoete, A. (2009). Mathematics and metacognition in adolescents and adults with learning disabilities. International Electronic Journal of Elementary Education, 2(1), 82-100. https://www.iejee.com/index.php/IEJEE/article/view/259

Eden, G. F., Wood, F. B., \& Stein, J. F. (2003). Clock drawing in developmental dyslexia. Journal of Learning Disabilities, 36(3), 216-228. https://doi.org/10.1177/002221940303600302 

BECERILLRININN ÖĞRETIMMININ ETKİLILİĞİ

Erbaş, D. (2008). Özel gereksinimli öğrencilere genel para kullanımını öğretme [Money use instruction for special needs students]. Ankara Üniversitesi Eğitim Bilimleri Fakültesi Özel Ĕ̈itim Dergisi, 9(1), 35-52. https://doi.org/10.1501/Ozlegt_0000000113

Flores, M. M., \& Kaylor, M. (2007). The effects of a direct instruction program on the fraction performance of middle school students at-risk for failure in mathematics. Journal of Instructional Psychology, 34(2), 8495. http://mathenrich.pbworks.com/w/file/fetch/52432358/EffectsofaDirect.pdf

Frank, A. R., \& MacFarland, T. D. (1980). Teaching coin skills to EMR children: A curriculum study. Education and Training of the Mentally Retarded, 15(4), 270-278. https://www.jstor.org/stable/23889297

Grobecker, B. (2000). Imagery and fractions in students classified as learning disabled. Learning Disability Quarterly, 23(2), 157-168. https://doi.org/10.2307/1511143

Gürsel, O. (2017). Matematik öğretiminde etkili yaklaşımlar. O. Gürsel (Ed.), Özel gereksinimli ögrencilere matematik beceri ve kavramlarının ögretimini planlama ve uygulama [Planning and applying the teaching of mathematical skills and concepts to students with special needs] içinde (ss. 83-108). Vize Basin Yayın.

Hill, J., \& MacMillan, R. C. (2004). An effective, research-based instructional approach to meet the needs of all students: Direct instruction. The case for employing direct instruction in America's schools. Special Education and Communication Disorders Faculty Publications. https://files.eric.ed.gov/fulltext/ED490519.pdf

Horn, C., Schuster, J. W., \& Collins, B. C. (2006). Use of response cards to teach telling time to students with moderate and severe disabilities. Education and Training in Developmental Disabilities, 41(4), 382-391. https://www.jstor.org/stable/23879664

Horner, R. H., Carr, E. G., Halle, J., McGee, G., Odom, S., \& Wolery, M. (2005). The use of single-subject research to identify evidence-based practice in special education. Exceptional Children, 71(2), 165-179. https://doi.org/10.1177/001440290507100203

Joseph, L. M., \& Hunter, A. D. (2001). Differential application of a cue card strategy for solving fraction problems: Exploring instructional utility of the cognitive assessment system. Child Study Journal, 31(2), 123-136. https://go.gale.com/ps/i.do?p=HRCA\&u=anon a385ddcc\&id=GALE|A81143124\&v=2.1\&it=r\&sid=bo okmark-HRCA\&asid=10b6e293

Kalaycı, H. E. (2014). Gelişimsel yetersizliği olan ögrencilere para kullanarak ürün satın alma becerisinin ögretiminde sonraki lira stratejisinin etkililiği [The effectiveness of one-more-than strategy in teaching purchasing skills by using money for students with developmental disabilities] (Tez Numaras1: 361717) [Yüksek lisans tezi, Anadolu Üniversitesi]. Yükseköğretim Kurulu Ulusal Tez Merkezi.

Karabulut, A., \& Y1kmış, A. (2010). Zihin engelli bireylere saat söyleme becerisinin öğretiminde eşzamanlı ipucuyla öğretimin etkililiği [The effectiveness of simultaneous prompting on teaching the skill of telling the tıme to individuals with mental retardation]. Abant İzet Baysal Üniversitesi Eğitim Fakültesi Dergisi, 10(2), 103-113. https://dergipark.org.tr/tr/download/article-file/16708

Kırcaali-İftar, G., \& Tekin, E. (1997). Tek denekli araştırma yöntemleri [Single subject research methods]. Türk Psikologlar Derneği.

Kibby, M. Y., Cohen, M. J., \& Hynd, G. W. (2002). Clock face drawing in children with attentiondeficit/hyperactivity disorder. Arch Clin Neuropsychol, 17(6), 531-46. https://doi.org/10.1093/arclin/17.6.531

Kurtoğlu, S., Tekinarslan, E., \& Çifci-Tekinarslan, İ. (2017). Zihinsel yetersizliği olan bireylere bankamatikten para çekme becerisinin öğretiminde bilgisayar destekli video öğretiminin etkililiği [The effect of computer aided video instruction in teaching money withdrawal skill from atm to individuals with intellectual disabilities]. Ankara Üniversitesi Ĕ̈itim Bilimleri Fakültesi Özel Eğitim Dergisi, 18(2), 185208. https://doi.org/10.21565/ozelegitimdergisi.321627

Lewis, K. E. (2016). Beyond error patterns: A sociocultural view of fraction comparison errors in students with mathematical learning disabilities. Learning Disability Quarterly, 39(4), 199-212. https://doi.org/10.1177/0731948716658063 

BECERILERININ ÖĞRETIMININ ETKILILIIIGII

Llorente, C., \& Gaffan, E. A. (1989). Coin identification and relative value: A training program for adults with $\begin{array}{llll}\text { mental handicap. Behavioural } & \text { Psychotherapy, 17(4), }\end{array}$ https://doi.org/10.1017/S0141347300017079

Lowe, M. L., \& Cuvo, A. J. (1976). Teaching coin summation to the mentally retarded. Journal of Applied Behavior Analysis, 9(4), 483-489. https://doi.org/10.1901/jaba.1976.9-483

Misquitta, R. (2011). A review of the literature: Fraction instruction for struggling learners in mathematics. Learning Disabilities Research \& Practice, 26(2), 109-119. https://doi.org/10.1111/j.15405826.2011.00330.x

Öncül, N., \& Özkan-Yücesoy, S. (2010). Orta ve ileri düzeyde yetersizliği olan yetișkinlere videoyla model olma kullanılarak günlük yaşam becerilerinin öğretilmesi [Teaching the daily living skills to adults with moderate and severe intellectual disabilities using video modeling]. Anadolu Üniversitesi Sosyal Bilimler Dergisi, 10(3), 143-156. https://www.acarindex.com/dosyalar/makale/acarindex-1423869487.pdf

Özel Eğitim Hizmetleri Yönetmeliği [Regulation of Special Education Services]. (2018). T.C. Resmi Gazete, (30471), 7 Temmuz 2018, 22-77.

Schloss, P., Kobza, S., \& Alper, S. (1997). The use of peer tutoring for the acquisition of functional math skills among students with moderate retardation. Education and Treatment, 20(2), 189-208. https://www.jstor.org/stable/42899488

Stein, M., Kinder, D., Silbert, J., \& Carnine, D. W. (2005). Designing effective mathematics instruction: A direct instruction approach. Pearson.

Suh, J. M., \& Moyer, P. S. (2008). Scaffolding special needs students' learning of fraction equivalence using virtual manipulatives. Proceedings of the International Group for the Psychology of Mathematics Education, 4(1), 297-304. http://mason.gmu.edu/ jsuh4/tenure/part4thru8/papers/RR.PME32.pdf

Şahin, Ö. (2017). iOS platformunda görme engelliler için TL tanıma uygulaması [Turkish banknote recognition application for visually impaired] (Tez Numarası: 489324) [Yüksek lisans tezi, Selçuk Üniversitesi]. Yükseköğretim Kurulu Ulusal Tez Merkezi.

Şenbel-Erten, Z. (1996). Zihinsel engelli öğrencilere üniteye dayalı olarak hazırlanan bireyselleştirilmiş kağıt para kavramı öğretim materyalinin açı anlatımla sunulmasının amaçların gerçekleşmesine yol açma düzeyi [The level of achieving the goals of mentally retarded students by presenting the individualized paper money concept teaching material based on the unit] (Tez Numarasi: 52662) [Yüksek lisans tezi, Gazi Üniversitesi]. Yükseköğretim Kurulu Ulusal Tez Merkezi.

Tekin, E. (1999). Yanlışsız öğretim yöntemleri [Errorless teaching methods]. Ankara Üniversitesi Ĕgitim Bilimleri Fakültesi Özel Eğitim Dergisi, 2(3), 87-102. https://doi.org/10.1501/Ozlegt_0000000043

Test, D. W., \& Ellis, M. F. (2005). The effects of LAP fractions on addition and subtraction of fractions with students with mild disabilities. Education \& Treatment of Children, 28(1), 11-24. https://www.jstor.org/stable/42899825

Test, D. W., Howell, A., Burkhart, K., \& Beroth, T. (1993). The one-more than technique as a strategy for counting money for individuals with moderate mental retardation. Education and Training in Mental Retardation, 28(3), 232-241. https://www.jstor.org/stable/23878788

Thompson, J. L., Wood, C. L., Test, D. W., \& Cease-Cook, J. (2012). Effects of direct instruction on telling time by students with autism. Journal of Direct Instruction, 12(1), 1-12. https://www.researchgate.net/publication/262731575_Effects_of_Direct_Instruction_on_Telling_Time_ by_Students_with_Autism

Trace, M. W., Cuvo, A. J., \& Criswell, J. L. (1977). Teaching coin equivalence to the mentally retarded. Journal of Applied Behavior Analysis, 10(1), 85-92. https://doi.org/10.1901/jaba.1977.10-85 

BECERILERININ ÖĞRETIMININ ETKILILİĞİ

Tufan, S., Tiryaki, D., \& Arslantekin, B. (2020). Zihinsel yetersizliği olan öğrencilere tam saatleri ayırt etme becerisinin öğretiminde doğrudan öğretim modelinin etkililiği [Effectiveness of direct instruction model on teaching identification of full hours to students with intellectual disabilities]. Ankara Üniversitesi Eğitim Bilimleri Fakültesi Özel Eğitim Dergisi, 21(4), 757-787. https://doi.org/10.21565/ozelegitimdergisi.595152

Tümeğ, S., \& Sazak-Pınar, E. (2016). Zihin yetersizliği olan öğrencilere madeni paraların öğretiminde zihin yetersizliği olan bir akran tarafindan sunulan eşzamanlı ipucuyla öğretim yönteminin etkililiği [The effectiveness of simultaneous prompting teaching procedure on teaching coins to students with intellectual disabilities by a peer with intellectual disabilities]. Ankara Üniversitesi Eğitim Bilimleri Fakültesi Özel Eğitim Dergisi, 17(3), 269-297. https://doi.org/10.21565/ozelegitimdergisi.267317

Vukmir, L. (2002). Direct instruction-a quiet revolution in Milwaukee public schools. Wisconsin Interest, 2(2), 41-50. https://www.heartland.org/template-assets/documents/publications/9145.pdf

Waters, H. E., \& Boon, R.T. (2011). Teaching money computation skills to high school students with mild intellectual disabilities via the TouchMath Program: A multi-sensory approach. Education and Training in Autism and Developmental Disabilities, 46(4), 544-555. https://www.jstor.org/stable/24232365

Yıkmış, A., Çifci-Tekinarslan, İ., \& Sazak-Pınar, E. (2006). Zihin engelli öğrencilere etkileşim ünitesi yöntemiyle yeni türk lirası ve yeni kuruş öğretimi [Teaching new Turkish lira and new kurus to mentally retarded students with the interaction unit method]. Abant İzzet Baysal Üniversitesi Eğitim Fakültesi Dergisi, 6(2), 19-36. https://dergipark.org.tr/tr/pub/aibuefd/issue/1490/18007

Yüksel, E. (2012). Zihin engelli çocuklara paraları tanıma becerisinin öğretiminde sabit bekleme süreli öğretimin etkililigi [The effectiveness of constant time delay instruction in teaching the skill of identifying money to mentally handicapped children] (Tez Numaras1: 304278) [Yüksek lisans tezi, Abant İzzet Baysal Üniversitesi]. Yükseköğretim Kurulu Ulusal Tez Merkezi. 


\section{Ankara University Faculty of Educational Sciences Journal of Special Education}

2022, 23(3), 507-535
RESEARCH

Recieved Date: 03.07.20

Accepted Date: 21.07.21

OnlineFirst: 24.09 .21

\title{
Effectiveness of Teaching Functional Mathematical Skills to Students with Developmental Disability via Direct Instruction Method*
}

\author{
Özer Akgün $(i$
}

\author{
Oğuz Gürsel iD2
}

\begin{abstract}
Introduction: Individuals with developmental disability require an education inclusive of academic and functional mathematical skills. The purpose of this study is to examine the effectiveness of teaching functional mathematical skills (telling time to the half hour, telling the total amount of the same coins and telling/reading the fractions) to students with developmental disability via direct instruction method.

Method: Multiple probe design with probe conditions across behaviors, a type of single-subject research design, was used in the research. The study was conducted with three students with developmental disability at the age of 9-10. The dependent variable was the ability to express the functional mathematical skills. The independent variable of the study was the direct instruction method.

Findings: Research findings showed that the direct instruction method was effective in teaching students with developmental disability how to tell time to the half hour, the total amount of the same coins and the fractions which were among the functional mathematical skills. It was observed that the students were able to maintain their functional mathematical skills and generalize this skill with different tools 5, 7 and 12 days following the end of the instruction.

Discussion: The performances of all the participant students significantly increased in the baseline phase probe sessions held before the education and in the daily probe and collective probe sessions conducted after the sessions with respect to the functional mathematical skills.
\end{abstract}

Keywords: Developmental disability, direct instruction method, functional mathematical skills, half hours, count coins, fraction skill.

To cite: Akgün, Ö., \& Gürsel, O. (2022). Effectiveness of teaching functional mathematical skills to students with developmental disability via direct instruction method. Ankara University Faculty of Educational Sciences Journal of Special Education, 23(3), 507-535. https://doi.org/10.21565/ozelegitimdergisi.763670

\footnotetext{
*This study is based on the master's thesis study conducted by Özer Akgün on the 2018-2019 academic year under the supervision of Assist. Prof. Dr. Oğuz Gürsel in European University of Lefke Institute of Graduate Studies \& Research. Furthermore, this study has been presented in the 29th National Special Education Congress as a verbal statement.

${ }^{1}$ Corresponding author: Specialist, Ministry of National Education, E-mail: akgunozer@ hotmail.com, https://orcid.org/00000001-5130-7924

${ }^{2}$ Assist. Prof., European University of Lefke, E-mail: gurselogz@gmail.com, https://orcid.org/0000-0002-4320-210X
} 


\section{Introduction}

Learning needs of the individuals which require special education differ due to their specific characteristics. They have the right to pursue their education via "person-centered" education model and education program in accordance with their characteristics and needs. Methods and techniques suited for the individual must be chosen in the learning and the teaching process pertinent to the purpose of the education model or the program (Ministry of National Education [MoNE], 2018). Direct instruction methods are one of these techniques.

The main notion behind direct instruction method is the necessity to design the education in such a way that all the children can learn through providing planned, thorough, and excellent learning experience in the instruction. Direct feedback and positive reinforcement are among the essential factors of this method. Unlikethe traditional education system, direct feedback and positive reinforcement used in this method is provided to the children explicitly and the children is being reinforced directly. This method proved to be significantly effective transforms the teaching into a student-centered learning through concrete and practical activities. Three stage teaching process is named as "I do, We do and You do" (Hill \& MacMillan, 2004). The steps of direct instruction method are as follows; a) program-based evaluation, b) instruction planning, c) preparation phase, d) being a model, e) guided practices, f) feedback and improvement, g) independent practices, h) permanence (Gürsel, 2017).

Individuals with developmental disability require an education inclusive of academic and functional mathematical skills. Functional mathematical skills focus on teaching real-life situations such as telling the time, using money, and measuring (Burton et al., 2013). Functional academic skills (counting money, time management, reading the billboards, etc.) must be included in the curriculum of the students in need of special education. These skills in the curriculum of the students with special education must be taught by associating them with real life. Enabling students with special needs to use the knowledge they have acquired in the school in the daily life same as the students with typical development are among the main purposes (Gürsel, 2017).

It is believed that this study will contribute to students with developmental disability in terms of learning functional mathematical skills. Previous studies report that direct instruction method is effective in the education of individuals with developmental disability. However, among the functional mathematical skills, only three studies were found on teaching individuals with developmental disability how to tell the time using direct instruction method. There were not any studies with respect to teaching the skills of how to tell the fractions and count the coins. This was the rationale behind the design and implementation of this study.

The general purpose of the research is to determine the effectiveness of teaching functional mathematical skills (telling the fractions, counting/calculating coins and telling the time) to students with developmental disability via direct instruction method. In this study, answers were sought for the following questions: Is direct instruction method effective for the students with developmental disability to a) acquire, b) maintain and c) generalise their functional mathematical skills to different materials. Furthermore, social validity was examined in the study.

\section{Method}

\section{Research Model}

Multiple probe design with probe conditions across behaviors, a type of single-subject research design, was used in the research. Functional mathematical skills were the dependent variable. The direct instruction method was the independent variable.

\section{Participants}

A total of 3 students including 2 male and 1 female 4th grade students with developmental disability who received a resource room report participated in the study. Prerequisite skills including (a) recognizing the numbers from 1 to 25, (b) telling the full hours, (c) ability to call the hour-hand the short arm and the minute hand the long arm, (d) rhythmic counting by fives, tens and twenty-fives, (e) recognizing 5 Turkish kurus, 10 Turkish kurus and 25 Turkish kurus, (f) comprehension of part to whole relationship and (g) apprehending the concepts of whole, half and quarter were required for the students who would participate in the study.

\section{Environment}

The baseline phase, instructional, probe, generalization and maintenance sessions of the research were conducted in the resource room of the school in the form of one-on-one sessions. Among the materials used in the teaching process, following adjustments were made; (a) with respect to half-hours, front window and the second 
hand were removed, real analog wall clock was presented, (b) in regard to coins, 5 Kurus, 10 Kurus and 25 Kurus coins, 5 for each and (c) in respect to fractions, $22 \times 22 \mathrm{~cm} 6$ PVC coating fraction teaching material split into different pieces in the shape of a circle whose parts were partially colored in green were prepared.

Among the materials used in the generalization sessions, following adjustments were made; (a) with respect to half-hours, front window and the second hand were removed, real analog table clock was presented, (b) in regard to coins, worksheet containing the picture of 5 Kurus, 10 Kurus and 25 Kurus coins, 5 for each and (c) in respect to fractions, the work sheet containing the picture of 6 rectangle shapes split into different pieces whose parts were partially colored in green were prepared.

\section{Implementation Process}

Baseline phase, instructional phase, daily and collective probe, generalization and maintenance sessions were performed in the implementation process. In the implementation process, among the functional mathematical skills, it was aimed to enable students to acquire the skills of telling the half-hours, telling the total amount of the same coins and telling the fractions via direct instruction method. The implementation was executed with all three students through one-on-one teaching arrangement. Skills were provided to students in different orders for the purpose of controlling the covariance effect between the skills in the implementation process. The criterion in this study were determined as $80 \%$ accuracy for the skill of telling the half-hours, $100 \%$ accuracy for the skill of telling the total amount of the same coins and $100 \%$ accuracy for the skill of telling fractions. For the purpose of demonstrating the effectiveness of the method used through making a comparison between the current performances of the students before and after the education in respect to the skills to be taught, baseline phase probe sessions were performed until obtaining at least 3 stable data synchronously and consecutively with the students for all the skills before the session. Instructional sessions were held with students after the baseline phase sessions. In the instructional sessions, collective probe sessions were held with the student after having shown a performance which met the criterion in the education of the first skill and obtaining at least 3 stable data. In the collective probe sessions conducted after the education of the first skill, the instruction of the second skill was commenced after obtaining at least 3 stable data. Collective probe sessions were held for all the skills after having shown a performance which met the criterion in the instruction of the second skill and obtaining at least 3 stable data. In the collective probe sessions conducted after the education of the second skill, the instruction of the third skill was commenced after obtaining at least 3 stable data. Collective probe sessions were held for the last time with respect to all the skills after the student showing a performance which met the criterion in the education of the third skill and obtaining at least 3 stable data. This procedure was applied for all the students. It was targeted that students would demonstrate the determined criterion for the three sessions in a row in order to complete the instruction. Monitoring data were collected 5, 7 and 12 days after reaching the criterion determined for all the skills in three sessions in a row. Moreover, generalization sessions were held between the instruments separately for all the skills shortly after reaching the criterion in all the skills.

Baseline phase sessions: In the baseline phase probe sessions, the process was designated as follows: "Teacher and the student sit face to face to the desk in the classroom. When the student gets ready, the teacher asks the student "What time is it?" by showing the first half-hour which is among the teaching materials with respect to the skill to tell the half-hours. Answers received from the student are processed to the data registration form for baseline phase probe session. The data for telling the total amount of the same coins and telling the fractions on the other hand, are collected by conducting the same process with the student. At the end of the session, the student's behavior is reinforced verbally by the teacher by saying: "Well done! You have participated in the study. Thank you".

Instructional sessions: In the baseline phase probe sessions, after having obtained at least 3 stable data from the students synchronously and consecutively, it was proceeded to the instruction of the skills in the form of one-on-one instructional sessions with each student via direct instruction method (being a model, guided practices and independent practices). The instruction of the skills was implemented as follows:

Instructional sessions were held with Mert for the skills of telling the total amount of the same coins, telling the half-hours, and telling the fractions, respectively. Instructional sessions were organized with Emir for the skills of telling the half-hours, telling the fractions, and telling the total amount of the same coins, respectively. Instructional sessions were conducted with Ayşe for the skills of telling the fractions and telling the total amount of the same coins and telling the half-hours, respectively. In the instructional session, collective probe sessions were held for all the skills after meeting the criterion in the first skill. It was proceeded to the instruction of the second skill afterwards. In the second skill, collective probe sessions were organized once again after meeting the 
criterion. The instruction of the third skill was implemented afterwards. Instructional sessions were completed after meeting the criterion in the third skill as well. Collective probe sessions were held for all the skills in the same way. In the instructional sessions, two trials were performed for the skills in the teaching set. One-on-one instructional sessions were held for all the students in every weekday in the way to perform the practices with all the students.

\section{Daily Probe Sessions}

Daily probe sessions were held after each instructional session for the skill that was taught with the intention of determining the student's performance after the instruction. The only difference of daily probe sessions from the collective probe sessions was that data was collected for only the skill taught instead of collecting data for all the skills. In the daily probe sessions for the skill that was taught, it was proceeded to the instruction of the other skill after the student showed at least 3 stable data consecutively.

\section{Collective Probe Sessions}

These were the sessions organized separately for each skill towards all the students after they showed a performance meeting the criterion and after obtaining stable data from them. Collective probe sessions were held for 3 skills separately and in one-on-one sessions with students after the criterion was met. Collective probe sessions were arranged after the students showed a performance meeting the criterion in the instruction of the first skill and at least 3 stable data were obtained. In the collective probe sessions performed after the instruction of the first skill, it was proceeded to the instruction of the second skill after obtaining at least 3 stable data. Collective probe sessions were held for all the skills after the students showed a performance meeting the criterion in the instruction of the second skill and at least 3 stable data were obtained. In the collective probe sessions performed after the education of the second skill, it was proceeded to the instruction of the third skill after obtaining at least 3 stable data. Collective probe sessions were held for all the skills for the last time after the students showed a performance meeting the criterion in the instruction of the third skill and at least 3 stable data were obtained.

\section{Generalizing Sessions}

Generalizing sessions were arranged in pre-test and post-test form. In the study, generalization among the instruments were performed. Pre-test sessions were held shortly after the baseline phase probe session while the post-test ones were performed after meeting the criterion in all the skills. Generalization sessions were conducted in a one-on-one education setting with different instruments.

\section{Maintenance Sessions}

Maintenance sessions were held for the purpose of determining to what extent the students maintained the skills they learned 5, 7 and 12 days following the instruction. The same process applied in the collective probe sessions was implemented in the maintenance sessions as well.

\section{Data Collection}

In this study, three types of data were collected including effectiveness, reliability, and social validity data. In the collection of the data for effectiveness, data was collected from the students in the baseline phase probe, daily and collective probe, instructional, maintenance, and generalizing sessions. Two types of student reaction were obtained during data collection. In the data registration form, for the appropriate reactions given by the student, "+" sign was marked under the 'Appropriate Reaction' column, for the inappropriate reactions, "-." was marked under the 'Inappropriate Reaction' column and “-” was marked under the 'No response' column in the case of unresponsiveness. The behavior of the student was regarded as inappropriate in cases where the student remained unresponsive. In the collection of reliability data, two types of data were collected as inter-observer reliability and application reliability. In at least $30 \%$ of the study, data for inter-observer reliability and application reliability were collected. Social validity data were collected by receiving the opinions of the participant students' classroom teachers regarding the study.

\section{Data Analysis}

Data obtained for the effectiveness of the direct instruction method was analyzed via graphical analysis. The horizontal axis of the prepared graphic consisted of the number of sessions while the vertical axis consisted of the percentage of right reaction towards the targeted behavior. Data on generalization sessions were shown in column chart through the analysis of pre-test and post-test model. Data obtained for the maintenance session were 
analyzed by the graphical analysis. In the analysis of social validity data, close-ended questions were analyzed. Regarding the open-ended questions, content analysis was conducted qualitatively.

\section{Findings}

\section{Findings Regarding Effectiveness}

When the research findings of Mert were examined, it was observed that he met the targeted criterion in the skill of telling the total amount of the same coins after 3 instructional sessions, in the skill of telling the halfhours after 5 instructional sessions and in the skill of telling the fractions after 5 instructional sessions and the education was concluded. When the research findings of Emir were examined, it was observed that he met the targeted criterion in the skill of telling the half-hours after 10 instructional sessions, the skill of telling the fractions after 7 instructional sessions and in the skill of telling the total amount of the same coins after 7 instructional sessions and the education was concluded. When the research findings of Ayşe were examined, it was observed that she met the targeted criterion in the skill of telling the fractions after 5 instructional sessions, in the skill of telling the total amount of the same coins after 5 instructional sessions and in the skill of telling the half-hours after 6 instructional sessions and the instruction ended. According to the findings, it was observed that direct instruction method was effective in the instruction of functional mathematical skills for Mert, Emir and Ayşe.

\section{Findings Regarding the Monitoring}

The monitoring data was collected 5, 7 and 12 days after reaching the targeted criterion for each 3 skills. It was observed that Mert, Emir and Ayşe maintained their acquired ability to tell the time at the rate of $100 \%$, average of $86 \%$ and average of $89 \%$ respectively. It was observed that Mert, Emir and Ayşe maintained their acquired ability to count money at the rate of $100 \%$, average of $100 \%$ and average of $100 \%$ respectively. It was observed that Mert, Emir and Ayşe maintained their acquired ability to tell the fractions at the rate of $100 \%$, average of $100 \%$ and average of $100 \%$ respectively.

\section{Generalization Findings}

When the findings were examined, the pre-test data of Mert for the skill of telling the total amount of the same coins $0 \%$ and post-test data was at $100 \%$; the pre-test data for the skill of telling the half-hours was at $0 \%$ and the post-test data was at $100 \%$; the pre-rest data for the skill of telling the fractions was at $0 \%$ and the posttest data was at $100 \%$. The pre-test data of Emir for the skill of telling the total amount of the same coins $0 \%$ and post-test data was at $100 \%$; the pre-test data for the skill of telling the half-hours was at $0 \%$ and the post-test data was at 90\%; the pre-rest data for the skill of telling the fractions was at $0 \%$ and the post-test data was at $100 \%$. The pre-test data of Ayşe for the skill of telling the total amount of the same coins was at $\% 0$ and post-test data was at $100 \%$; the pre-test data for the skill of telling the half-hours was at $0 \%$ and the post-test data was at $90 \%$; the pre-rest data for the skill of telling the fractions was at $0 \%$ and the post-test data was at $100 \%$. In the generalization findings of the study, the students' pre-test, and post-test data showed that they were able to generalize the skills they learned through different instruments with high accuracy.

\section{Social Validity Findings}

In the social validity findings, participant teachers generally reported positive opinions with respect to teaching functional mathematical skills via direct instruction method. The teachers stated that they were pleased to be participating in this study, that functional mathematical skills were of high importance for the students and that there was a statistically significant difference for the improvement of these skills among students following the completion of the research.

\section{Reliability Findings}

Inter-observer reliability data was collected from the participants for each skill separately. Mert's interobserver reliability co-efficient for the skills was detected as minimum 98\% and maximum 100\%. Emir's interobserver reliability co-efficient for the skills was detected as minimum 98\% and maximum 100\%. Ayşe's interobserver reliability co-efficient for the skills was detected as minimum $98 \%$ and maximum $100 \%$.

Application reliability data was collected from the participants for each skill separately. Mert's application reliability co-efficient for the skills was detected as minimum 96\% and maximum 100\%. Emir's application reliability co-efficient for the skills was detected as minimum $98 \%$ and maximum $100 \%$. Ayşe's application reliability co-efficient for the skills was detected as minimum $98 \%$ and maximum $100 \%$. 


\section{Discussion}

According to the findings obtained from the research, it was observed that; (a) the direct instruction method used in this study was effective in teaching functional mathematical skills to the students with developmental disability, (b) that the students were able to maintain these skills they learned in the maintenance sessions 5,7 and 12 days after the completion of the instruction, (c) that they could generalize these skills they learned in the generalization sessions held after the completion of the instruction with different instruments and (d) that the classroom teachers of the participant students delivered a positive opinion in general with regard to the social validity of the study.

These findings obtained in the study show similarity with the findings obtained in the other studies examining the effectiveness of teaching functional mathematical skills via direct instruction method (Birkan, 2012; Dağseven, 2001; Flores \& Kaylor, 2007; Lowe \& Cuvo, 1976; Tufan et al., 2020). It was seen that the performances of all the participant students significantly increased in the baseline phase probe sessions held before the education and in the daily probe and collective probe sessions conducted after the education with respect to the functional mathematical skills. After the education, students' functional mathematical skills reached to an independently accomplishable level. The findings show that the direct instruction method is an effective method in teaching functional mathematical skills to three students with developmental disability.

In the teaching phase, it was observed that, contrary to Mert's and Ayşe's correct response rates, instead of a steady increase, a wave-like performance was seen in Emir's correct response rates on the ability to tell the time and count money. A sudden decrease in Emir's ability to tell the time especially in the 6th teaching phase was noteworthy. The reason behind this was that Emir read the relevant half-hour incorrectly as he set the hour hand and the minute hand of the four and a half hour which was the expected task in the 6th teaching phase. Emir confused 12:30 with 6:30 as of the position of short (hour-hand) and long hand (minute hand). He often confused 5:30 with 7:30. In the determined half hours, the short and long hand was close to each other. Telling the hour which stayed above the short hand on the right half while telling the hour which stayed below the short hand on the left half caused the student to confuse these with each other.

Showing the relevant half hour incorrectly and/or not being able to read it was marked as "-" on the registration form. These hours confused by the participant in the same session caused a sudden decrease in Emir's performance. In the teaching process, Emir reached 100\% performance 2 sessions after (8th session) becoming used to the difference between these hours. Emir continued to show a performance at a level which mets the criterion also in 9th and 10th sessions after achieving the skill with a 100\% accuracy. The reason behind Emir's sudden decrease regarding the ability to count money in the 2 nd and 4th teaching session was that he performed the counting process in a rhythmic counting pace when sorting the money. Accordingly, he counted the coins too little or too many and told the total amount incorrectly since he had not performed the counting process simultaneously when sorting the money. Emir could not tell the total amount of the money correctly and this skill was marked as "-" on the registration form since he had performed an incorrect counting session. The inappropriate counting included three different money counting skills in the 2nd session, 25 kurus coins in the 3rd session and 5 and 25 kurus coins in the 4th session. Emir performed the skill with a $100 \%$ accuracy in the other sessions following the conclusion that he needed to perform the counting process simultaneously when counting the money by sorting them.

According to the study findings, the one that all 3 students made a mistake the most and the one that all of them acquired in the longest period was the ability to tell the half hours. This finding showed resemblance to the findings obtained in other studies regarding the ability to tell the time (Andersson, 2008; Burny et al., 2011; Desoete, 2009). In the ability to tell the full hours, the short hand of the clock clearly shows any time of the hour while the short hand in the half hours shows the middle of the two consecutive hours. Therefore, it was projected that students had difficulty in acquiring the ability to tell the half hours. As a result, it was observed that students had difficulty in deciding whether they were supposed to tell the hour that came before or after two consecutive hours. The studies emphasized that it was not only necessary to teach the students the ability to tell the time, figure out the amount of money and tell the fractions but also to show them how use these skills fluently and to continue to maintain these skills after the education (Browder \& Grasso, 1999). Therefore, the second finding of the study exhibited that the participants maintained their ability to tell the half hours, tell the total amount of the same coins and tell the fractions which were taught in the monitoring sessions performed 5, 7 and 12 days after the completion of the instruction and that these skills obtained were permanent. 

DEVELOPMENTAL DISABILITY VIA DIRECT INSTRUCTION METHOD

Previous research did not examine the effectiveness of the direct instruction method on teaching the skills of counting coins and telling the fractions to students with developmental disability. This study showed the effectiveness of the direct instruction method on teaching how to tell the total amount of the same coins and how to tell the fractions. Within this context, this study is essential in terms of being the first research in Turkey conducted with the students with developmental disability with respect to teaching them the skills of counting coins and telling the fractions. In the literature, there are only three studies in the field of teaching the skill of telling time to students with developmental disability. This study aiming at teaching the skill of telling half-hours to students with developmental disability in Turkey is expected to contribute to the development of the literature as well. Future studies can be designed and conducted with the instruction of functional mathematical skills such as telling the total amount of different coins (50 Turkish kurus, 1 Turkish lira), telling the compound fractions, telling the quarter hours or digital hours.

\section{Authors' Contributions}

This study is based on the master's thesis study conducted by Özer Akgün under the supervision of Assist. Prof. Dr. Oğuz Gürsel. For this reason, the subject of the study, the research design, the analysis of the data and the reporting of the study were determined and carried out by the two authors together. The data was collected by Özer Akgün. 